\title{
Etik tüketimin hedonik tüketim ve kompulsif satın alma davranışı üzerindeki etkisinin PLS-SEM ile incelenmesi
}

\author{
Analysis of the effect of ethical consumption on hedonic consumption \\ and compulsive purchasing behaviour with PLS-SEM
}

İbrahim Yemez ${ }^{1}$

1 Dr. Arş. Gör., Sivas Cumhuriyet Üniversitesi, İ̈BF, İşletme Böl., Sivas, Türkiye, ibrahimyemez@hotmail.com

ORCID: 0000-0003-3176-6394

Başvuru/Submitted: 1/03/2021

Revizyon/Revised: 12/04/2021

Kabul/Accepted: 20/04/2021

Yayın/Online Published: 25/08/2021

Atıf/Citation: Yemez, İ., Etik tüketimin hedonik tüketim ve kompulsif satın alma davranışı üzerindeki etkisinin PLS-SEM ile incelenmesi, tujom (2021) 6 (2):104-124, doi: https://doi.org/10.30685/tujom.v6i2.110
Öz

$\mathrm{Bu}$ çalışmada etik tüketimin hedonik tüketim ve kompulsif satın alma davranışı üzerindeki etkisi ortaya konulmaya çalışılmıştır. Bu amaçla 25-28 Aralık 2020 tarihlerinde online örnekleme yöntemiyle, 18 yaşından büyük toplam 564 kişiden veri toplanmıştır. Verilerin ilk olarak normal dağıldığı ortaya konulmuştur. İkinci aşamada PLS-SEM ile Doğrulayıcı Faktör Analizi yapılmış ve ölçek geçerliliği ve güvenilirliği kanıtlanmıştır. Daha sonra ise Yol Analizi ile model test edilmiştir. Analiz sonucunda Etik Tüketimin Hedonik Tüketimi pozitif ve yaklaşık \%13 oranında etkilediği; Hedonik Tüketimin Kompulsif Satın Alma Davranışını pozitif ve yaklaşık \%69 oranında etkilediği ancak Etik Tüketimin Kompulsif Satın Alma Davranışı üzerinde anlamlı bir etkisinin olmadığı da görülmüştür. Ayrıca model uyum skorlarına göre modelin iyi uyum gösterdiği görülmüştür. Son aşamada ise faktörlerin katılımcıların cinsiyet, medeni durum, yaş, eğitim, gelir, meslek ve yaşadıkları coğrafi bölgeye göre karşılaştırılmasında Bağımsız Örneklemler T Testi ve Tek Yönlü F testi kullanılmıştır. Faktörlerin bazı değişkenlere göre anlamlı farklılık gösterdiği görülmüştür.

Anahtar Kelimeler: Etik Tüketim, Hedonik Tüketim, Kompulsif Satın Alma Davranışı, PLS-SEM Jel Kodlari: M11, M31

\begin{abstract}
In this study, the effect of ethical consumption on hedonic consumption and compulsive buying behavior was tried to be revealed. For this purpose, data were collected from a total of 564 people over the age of 18 by online sampling method on 25-28 December 2020. It was revealed that the data were firstly distributed normally. In the second stage, Confirmatory Factor Analysis was performed with PLS-SEM and the validity and reliability of the scale were proven. Then, the model was tested with Path Analysis. As a result of the analysis, it was found that Ethical Consumption positively affects Hedonic Consumption by approximately 13\%; It was also observed that Hedonic Consumption had a positive effect on Compulsive Buying Behavior by about $69 \%$, but Ethical Consumption had no significant effect on Compulsive Buying Behavior. In addition, it was seen that the model showed good fit according to the model fit scores. In the last stage, the Independent Samples T-Test and One-Way F-test were used to compare the factors according to the participants' gender, marital status, age, education, income, occupation and geographic region. It was observed that the factors differed significantly according to some variables.
\end{abstract}

Keywords: Ethical Consumption, Hedonic Consumption, Compulsive Purchasing Behavior, PLSSEM

Jel Codes: M11, M31 


\section{Extended Abstract}

\section{Analysis of the effect of ethical consumption on hedonic consumption and compulsive purchasing behaviour with PLS-SEM}

\section{Literature}

\section{Research subject}

Ethical consumption includes many social and ecological concerns, such as human rights, environment, animal welfare, local community initiatives, social justice issues, and many other issues (Carrigan et al., 2004). Based on all these definitions, ethical consumption can be defined as individuals with a high level of consciousness, showing a buying behaviour by paying attention to social justice, human rights, the environment, animal rights, social inequalities and reducing personal consumption, or stopping or boycotting certain products due to these concerns.

Hedonic consumption can be expressed as the sum of the emotional and subjective effects individuals leave on themselves when purchasing goods or services. Individuals' desire to buy a product because it has a special meaning shows that hedonic products have subjective and spiritual characteristics (Hanzaee \& Khonsari, 2011).

Compulsive buying can be defined as chronic and continuous/repetitive purchases made to respond to adverse events or emotions (O'Guinn \& Faber, 1992). In another definition, it is expressed as a chronic and repetitive type of behaviour developed in response to unfortunate events (McElroy et al., 1994). In this context, the subject of this study is the effect of ethical consumption on hedonic consumption and compulsive purchasing behaviour.

\section{Research purpose and importance}

This study aims to reveal the effect of ethical consumption on hedonic consumption and compulsive purchasing behaviour. In the first stage of the study, Confirmatory Factor Analysis was performed with PLS-SEM, and the validity and reliability of the scale were determined. In the second stage, Path Analysis was made with PLS-SEM, and the research model was tested. In the last stage, ethical consumption, hedonic consumption and compulsive purchasing behaviours were compared according to the demographic characteristics of the consumers.

In this study, structural equation modelling, enriching the relevant literature, and contributing to the literature reveal ethical consumption's effect on hedonic consumption and compulsive purchasing behaviour.

\section{Contribution of the article to the literature}

No study in the literature directly measures ethical consumption on hedonic consumption and compulsive purchasing behaviour. In this sense, this study contributes by enriching the relevant literature.

\section{Design and method}

\section{Research type}

The study is applied research. The study is also exploratory research.

\section{Research problems}

The main problem of the research is to reveal the effect of ethical consumption on hedonic consumption and compulsive buying behaviour. Its sub-problems are to determine whether ethical consumption, hedonic consumption and compulsive purchasing behaviour change according to the demographic characteristics of consumers.

\section{Data collection method}

The online sampling technique collected the data used in the study. The study group of the research consists of 564 people over the age of 18 . The data used in the study were collected by online survey method on 25-28 December 2020.

\section{Quantitative/qualitative analysis}

In the study, the standard distribution test was applied first, and it was found that the data were normally distributed. Confirmatory Factor Analysis was performed with PLS-SEM, and scale validity and reliability findings were presented in the second stage. In the third stage, the research model was tested with Path Analysis, and the effect of Ethical Consumption on Hedonic Consumption and Compulsive Purchasing Behavior was revealed. In the last stage, the factors were compared with the Independent Samples T-Test and One-Way F Test, which are parametric tests according to the participants' education, profession, gender, age, income, marital status and region of residence. Tukey and Tamhanes' T2 tests, among the Post-Hoc Multiple Comparison Tests, were used for the groups that differed.

\section{Research model}

The Research Model is shown in figure 1 below.

\section{Research hypotheses}

H1: Ethical Consumption has a significant effect on Hedonic Consumption.

H2: Hedonic Consumption has a significant effect on Compulsive Purchasing Behavior.

H3: Ethical Consumption has a significant effect on Compulsive Purchasing Behavior. 
H4: Ethical Consumption shows a significant difference according to the demographic characteristics of the participants.

H4.1: Ethical Consumption shows a significant difference according to the gender of the participants.

H4.2: Ethical Consumption shows a significant difference according to the age of the participants.

H4.3: Ethical Consumption shows a significant difference according to the education level of the participants.

H4.4: Ethical Consumption shows a significant difference according to the monthly average income of the participants.

H4.5: Ethical Consumption shows a significant difference according to the marital status of the participants.

H4.6: Ethical Consumption shows a significant difference according to the professions of the participants.

H4.7: Ethical Consumption shows a significant difference according to the region where the participants live.

H5: Hedonic Consumption shows a significant difference according to the demographic characteristics of the participants.

H5.1: Hedonic Consumption shows a significant difference according to the gender of the participants.

H5.2: Hedonic Consumption shows a significant difference according to the age of the participants.

H5.3: Hedonic Consumption shows a significant difference according to the education level of the participants.

H5.4: Hedonic Consumption shows a significant difference according to the monthly average income of the participants.

H5.5: Hedonic Consumption shows a significant difference according to the marital status of the participants.

H5.6: Hedonic Consumption shows a significant difference according to the professions of the participants.

H5.7: Hedonic Consumption shows a significant difference according to the region where the participants live.

H6: Compulsive Purchasing Behavior shows a significant difference according to the demographic characteristics of the participants.

H6.1: Compulsive Purchasing Behavior shows a significant difference according to the gender of the participants.

H6.2: Compulsive Purchasing Behavior shows a significant difference according to the age of the participants.

H6.3: Compulsive Purchasing Behavior shows a significant difference according to the education level of the participants.

H6.4: Compulsive Purchasing Behavior shows a significant difference according to the monthly average income of the participants.

H6.5: Compulsive Purchasing Behavior shows a significant difference according to the marital status of the participants.

H6.6: Compulsive Purchasing Behavior shows a significant difference according to the professions of the participants.

H6.7: Compulsive Purchasing Behavior shows a significant difference according to the region where the participants live.

\section{Findings and discussion}

\section{Findings as a result of analysis}

It was seen that the scale used in the study met the validity and reliability conditions. Later, the model was tested with Path Analysis. According to the analysis results, Ethical Consumption affects Hedonic Consumption positively and approximately 13\%; Hedonic Consumption has been found to affect Compulsive Purchasing Behavior positively and approximately $69 \%$, but Ethical Consumption has no significant effect on Compulsive Purchasing Behavior.

\section{Hypothesis test results}

Hypothesis testing results are given in Table 1 below.

\section{Discussing the findings with the literature}

The results obtained in the study are similar to the results of Phau \& Woo (2008), one of the previous studies. In the related study, students overspend, and in this study, students show more compulsive buying behaviour than some other professions.

The results obtained in the study differ in terms of some studies. For example, Kaderli et al. (2017), while consumers from generation $Y$ showed compulsive purchasing behaviour, in this study, it was observed that the age variable had no effect on compulsive purchasing behaviour and did not differ in terms of generations.

\section{Conclusion, recommendation and limitations}

\section{Results of the article}

Later, the model was subjected to Confirmatory Factor Analysis with PLS-SEM, the validity and reliability of the scale used in the study were examined, and it was seen that the scale provided convergent and coherent validity, and also that all factors and the scale had a coefficient of 0.7 and above, that is, it was reliable. Moreover, again, it was seen that the article's scale also provided decomposition validity. In other words, it has been revealed that the scale used in the study is both valid and reliable.

In the third step, the research model was tested with PLS-SEM. It was found that the goodness of fit scores of the model was in the acceptable range, and the model fit well. Again, in the model, it was observed that the coefficients of two of the road relations established between the factors were higher than 1.96, but one of them was small and therefore not significant. According to this, Ethical Consumption affects Hedonic Consumption positively and approximately 13\%; Hedonic 
Consumption has been found to affect Compulsive Purchasing Behavior positively and approximately $69 \%$, but Ethical Consumption has no significant effect on Compulsive Purchasing Behavior.

\section{Suggestions based on results}

In future studies, examining the effects of ethical consumption and different variables on hedonic consumption and compulsive purchasing behaviour may lead to different results. In this study, the subject has been examined in terms of all consumers. However, in future studies, only female or male consumers; if analyses are made on different samples such as young consumers and older consumers, different results can be obtained again.

\section{Limitations of the article}

One of the most significant limitations of the study is that the study is quantitative. The second biggest constraint is collecting data with the online sampling method. It can be said that the third biggest limitation of the study is the statistical analysis used. Future studies will be possible to reach different results by using different sampling methods and different analysis methods, and qualitative methods.

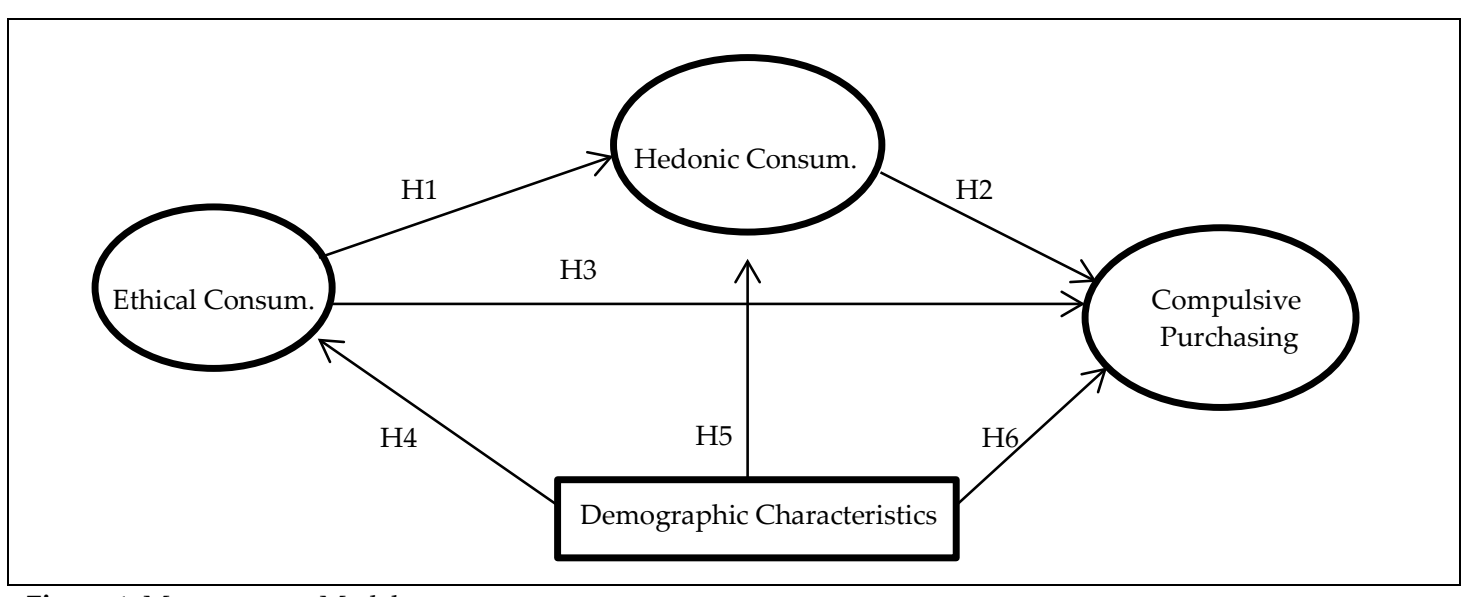

Figure 1: Measurement Model

Table 1: Hypothesis Testing Results

\begin{tabular}{|c|c|c|c|}
\hline Hypothesis & Results & Hypothesis & Results \\
\hline H1 & Supported & H5.3 & Supported \\
\hline H2 & Supported & H5.4 & Supported \\
\hline H3 & Rejected & H5.5 & Supported \\
\hline H4 & Rejected & H5.6 & Supported \\
\hline H4.1 & Rejected & H5.7 & Supported \\
\hline H4.2 & Rejected & H6 & Supported \\
\hline H4.3 & Rejected & H6.1 & Supported \\
\hline H4.4 & Rejected & H6.2 & Rejected \\
\hline H4.5 & Rejected & H6.3 & Supported \\
\hline H4.6 & Rejected & H6.4 & Supported \\
\hline H4.7 & Rejected & H6.5 & Rejected \\
\hline H5 & Supported & H6.6 & Supported \\
\hline H5.1 & Supported & H6.7 & Rejected \\
\hline H5.2 & Rejected & & \\
\hline
\end{tabular}




\section{Giriș}

Tüketicilerin bilinç seviyelerinin yükselmesi ve iletişim teknolojilerindeki gelişmelerin tüketicilerin birbirleriyle daha kolay ve daha sık iletişim kurmalarına imkân vermesiyle tüketim trendlerinde değişimler meydana gelmiştir. Son 40 yıldır etik tüketim ve sürdürülebilir tüketim konusundan farklı disiplinlerden bilim insanları araştırmalar yapmakta ve tüketicilerin etik alternatifleri satın alma, geri dönüşüm, kişisel tüketimi azaltma ve enerji tasarrufu sağlamak gibi nedenlerle sürdürülebilir tüketime yönlendiren motivasyonlar hakkında çalışmalar ortaya koymuşlardır (Antonetti ve Maklan, 2014, s.117).

Her geçen gün daha fazla sayıda işletme, sürdürülebilir kalkınma ilkelerini benimsediğinde, bunun çevre dengesi ve insan refahına sonuçlarını dikkate alma gereğinin farkına varmaktadır (Chow ve Chen, 2012). Aynı zamanda, ekoloji ve insan refahı konularının dikkate alınmasını içeren etik tüketici davranışı çarpıcı bir şekilde artmaktadır (Fairtrade International, 2013: akt: Sudbury ve Kohlbacher, 2016, s. 2697).

Tarihsel olarak etik tüketimin ortaya çıkısına bakıldığında etik tüketimin ilk olarak küçük bir ilkeli insan gurubunun tüketim davranışı olarak kendini gösterdiği görülmüştür. Bununla birlikte etik ürünlerle ilgili verilere erişimin kolaylığının artmasıyla etik markaların sayısı artmış ve bunun sonucu olarak da etik tüketici davranışı tanımlarıyla ilgili belirgin farklılıklar ortaya çıkmıştır ve bazı tanımlar eskisine nazaran daha akıcı bir hal almıştır. Örneğin, Adil Ticaret kavramı bu yeni tanımlardan biridir (Sudbury ve Kohlbacher, 2016, s. 2698).

Hedonik değer, tüketicilerin deneyimlerinden edindikleri keyif, eğlence ve olumlu duyguları ifade eder (El-Adly ve Eid, 2016). Ayrica Dedeoğlu, Bilgihan, Buonincontri ve Okumus (2018), hedonik değerin yenilik değeri ve duygusal değer aracıllğıyla yakalanabileceğini öne sürmüştür. Pazarlama disiplinindeki geleneksel bilgelik, müşterilerin fayda odaklı ve fayda maksimize ediciler olduklarını, finansal ödülleri maksimize etmeye ve işlemler sırasında maliyetleri en aza indirmeye çalıştıklarını ileri sürer (Bettman, Luce ve Payne, 1998). Bu bağlamda hedonik tüketim davranışı gösteren bir tüketicinin asıl amacının zevk ve keyfi almak olduğu ve bu amaçla alışveriş yaparak ruhsal rahatlık, günlük sıkıntıları ve problemleri unutma ve tatmin sağlamak amacıyla hareket ettiği söylenebilir.

Kompulsif satın alma davranışı ya da diğer adıyla takıntılı satın alma davranışı kişinin dürtüsel olarak satın alma güdüsü hissetmesi, bunu kontrol edememesi ve maddi zorluklara yol açan bir rahatsızlığ ifade eder. Bu konuda yapılmış çalışmalar, bu durumu bir hastalık olarak ele aldığı ve bu tür bir davranışı, dürtü kontrol bozukluğunun yaygın ve geniş kapsamlı bir alt sınıfı olduğunu ifade etmişlerdir. Yine yapılan çalışmalar, bu hastalığın yirmili yaşların başlarında ortaya çıktı̆̆ı, kronik olduğu, hastaların çoğunun kadın olduğu ve toplumda yaygınlığının yetişkinlerde \%2 ve \%16 arasında olduğunu ifade etmişlerdir (Black, 2007). Kompulsif satın alma davranışı bir tüketim eylemi olarak ifade edilse bile davranışın kökeninde bireyin dürtüsel bozukluğunun onu satın almak zorunda bırakmasının yattığı gerginlik vardır. Dolayısıyla bu tür bir davranış gösteren kişinin takıntılı bir durum sonucunda satın alma eylemini gerçekleştirdiği söylenebilir. Bu bağlamda bu çalışmada etik tüketimin hedonik tüketim ve kompulsif satın alma davranışı üzerindeki etkisinin ortaya konulması amaçlanmıştır. Çalışmada ilk aşamada PLS-SEM ile Doğrulayıcı Faktör Analizi yapılmış ve ölçeğin geçerliliği ve güvenirliği saptanmıştır. İkinci aşamada ise yine PLS-SEM ile Yol Analizi yapılmış ve araştırma modeli test edilmiştir. Son aşamada ise etik tüketim, hedonik tüketim ve kompulsif satın alma davranışları tüketicilerin demografik özelliklerine göre karşılaştırılmıştır.

Çalışmada etik tüketimin hedonik tüketim ve kompulsif satın alma davranışı üzerindeki etkisi yapısal eşitlik modellemesi ile ortaya konularak ilgili literatürü zenginleştirmekte ve literatüre katkı sağlamaktadır.

\section{Kavramsal çerçeve}

\section{Etik tüketim}

Küresel ekonomik genişlemenin hem çevresel hem de sosyal eşitsizlik üzerindeki yıkıcı sonuçları araştırmacıların, medyanın ve aktivist grupların dikkatini çekmiş; kısmen de olsa amaç, insanları tüketim ve satın alma davranışlarıyla nasıl fark yaratabilecekleri konusunda eğitmek olmuştur. Günümüzde, dünya çapındaki tüketicilerin büyük bir kısmı, kötüye kullanılan çalışma koşullarının, 
sosyal ve ekonomik eşitsizliğin yükselişinin, çevre kirliliğinin ve 'turbo kapitalizmin' diğer nedenlerinin farkındadır (Carrington ve Neville, 2016). Bu farkındalık, tüketicilerin ürün seçimlerini yaparken insan hakları, sosyal adalet ve çevreyi koruma dahil olmak üzere kendi etik ve çevresel kaygilarına öncelik verdikleri bir etik tüketim hareketine yol açmıştır (Kushwah vd., 2019; Shaw ve Clarke, 1998). Bu nedenle giderek artan sayıda tüketici, tutumlarını ve satın alma davranışlarını buna göre değiştirdiklerini iddia etmekte, tüketim için 'etik bir çağ' oluşturmakta ve sosyal ve çevresel açıdan sorumlu ürünler veya basitçe etik ürünler (Ethical Product'ler) için kamu talebinin de değişimini sağlamaya çalışmaktadırlar (Carrington vd., 2010).

Etik tüketimle ilgili yapılan tanımlarda en çok görülen temalar, sırayla, çevresel konular, sosyal adalet ve insan hakları, bilinçli olarak satın almamak ya da boykot etmek ve son olarak ise fiyattır (yüksek fiyat ödeme istekliliği)( Sudbury ve Kohlbacher, 2016, s. 2698-2699). Etik tüketim adil ticaret ya da çevre dostu ürünler gibi çeşitli etik seçimlerle güdülenen bir dizi satın alma girişimi olarak adlandırılır (Szmigin vd., 2006). Etik tüketim, geniş bir yelpazede gelişen, insan hakları, çevre, hayvan refahı, yerel topluluk girişimleri, sosyal adalet sorunları ve birçok diğer sorunlar gibi toplumsal ve ekolojik kaygıları içerir (Carrigan vd., 2004). Bütün bu tanımlardan yola çıkarak etik tüketimin bilinç seviyesi yüksek bireylerin sosyal adaleti, insan haklarını, çevreyi, hayvan haklarını, toplumsal eşitsizlikleri ve kişisel tüketimin azaltılması düşüncesini önemseyerek satın alma davranışı göstermesi ya da yine bu kaygılarından dolayı bazı ürünleri satın almayı bırakması veya boykot etmesi şeklinde tanımlanabilir. Etik tüketim anlayışına sahip bir tüketicinin zevk için ya da rahatlamak amacıyla satın alımlar gerçekleştirmeyeceği söylenebilir. Aksi durumda savunduğu değerlerle çatışma yaşayacağ için etik tüketim iddiası da boşa düşeceğinden etik tüketici davranışı gösteren bireyin savunduğu ilkelere aykırı davranması durumu ortaya çıkacaktır.

\section{Hedonik tüketim}

Bu kavram ilk olarak Hirscman ve Holbrook (1982) tarafından kullanılmış ve hedonik değer, bir tüketicinin bir ürüne yönelik olarak barındırdığı çoklu duyuşsal, fantezi, haz gibi yönlerin ve bunların bütünü olarak ifade edilmiştir. Hedonik tüketim bireylerin mal veya hizmet satın alırken, satın alacağı şeyin kendisinde bıraktığı duygusal ve öznel etkilerin toplamı olarak ifade edilebilir. Bireylerin bir ürünü, kendileri açısından özel bir anlam ifade etmesinden dolayı satın almak istemeleri hedonik yani hazcı ürünlerin öznel ve manevi özelliklere sahip olduğunu göstermektedir (Hanzaee ve Khonsari, 2011). El-Adly ve Eid (2015) hedonik değeri, alışveriş yapanların alışveriş merkezindeki alışveriş deneyimlerinden elde ettikleri eğlence ve keyif olarak tanımlarken, bu deneyimin kendini tatmin, stresi azaltma, alışveriş yapanların alışveriş deneyiminin sağladığ1 refahın iyileştirilmesi, olumsuz ruh hallerini değiştirme ve onları günlük rutinden ve problemlerden uzaklaştırma gibi yönlerinin olduğunu da ifade eder. Voss vd. (2003), ürün kategorilerine yönelik tüketici tutumlarının hedonik ve faydacı boyutlarını ölçmüşler. Faydacı yönlerin baskın öngörüleri olarak "kullanışlı", "faydalı" ve "işlevsel" kategorileri oluştururken, "zevkli", "eğlenceli" ve "neşeli" kategorileri ise hedonik yönlerin güçlü öngörücüleri olduğunu ileri sürmüşlerdir. Yani, faydacı tüketici davranışı işlevsel bir bakış açısı olarak tanımlanır ve iş olarak düşünülebilir. Ancak hedonik tüketici davranışı, eğlence gibi tüketici algısının daha keyifli yönleri olarak açıklanmaktadır (Babin vd., 1994). Wakefield ve Blodgett'a (1999) göre, müşterilerin hedonik ve faydacı tüketimleri her hizmet türü için farklılık gösterebilir. Örneğin, bir okula veya hastaneye giden bir kişi daha faydacı tüketim davranışı gösterebilirken, bir otele veya eğlence parkına giden bir kişi daha hedonik tüketim davranışı gösterebilir (Dedoğlu vd., 2018, s. 11).

Konuyu tasvir etmeye yönelik sayısız bilimsel çabaya rağmen, bir meslekten olmayan tanımın en geniş kapsamlı ve sezgisel olarak çekici yaklaşımı sağlayabileceğini öneriyoruz. Hedonik tüketimin hayati bir bileşeni, ürünü veya olayı tüketme deneyiminin zevkli olup olmadığıdır. Aslında, tüketimin pratik bir amaca hizmet edip etmediğine veya kendi yararları doğrultusunda takip edilmesine, ister istemli olarak ister tesadüfen gerçekleşsin ve diğer tüketim biçimleriyle karşılaştırılsın veya tek başına incelendiğine bakılmaksızın, hedonik tüketimin evrensel ve temel bir özelliği, zevkli olmasıdır (ve olmasının beklenmesidir) (Alba ve Williams, 2013, s. 4). Özetlemek gerekirse hedonik tüketim davranışında tüketicilerin öncelikli amaçlarının zevk, eğlence, mutluluk, tatmin olma, hoş vakit geçirme vb. gibi unsurlar olduğu ve satın alma eylemi gerçekleştirirken de faydacı güdüleri bir kenara bırakıp duygusal ve öznel yönlerine hitap eden ürünleri satın aldıkları görülmektedir. 


\section{Kompulsif satın alma davranışı}

Kompulsif satın alma, negatif olaylar ya da duygulara bir cevap olarak yapilan kronik ve sürekli/tekrarlı satın alımlar şeklinde tanımlanabilir (Faber ve O'Guinn, 1992, s. 459). Başka bir tanımda ise mutsuzluk veren olaylara tepki olarak geliştirilen kronik ve tekrarlayan bir davranış türüdür şeklinde ifade edilmiştir (McElroy vd., 1994). Eroğlu (2016)'na göre ise kompulsif satın alma davranışı kişinin doğuracağı sonuçları göz ardı ederek, yapmaktan kendini alı koyamadığı, çoğu zaman gereksiz ve kullanamayacağı ürünleri sürekli bir şekilde ve aşırı sayıda satın alması ve bunun sonucunda da pişmanlık duyması ile neticelenen bir tüketici davranışıdır. Araştırmalar, zorlayıcı satın alma davranışının, zihinsel rahatsızlıktan kurtulmak için tekrarlanan alımlar yapmaya yönelik güçlü bir iç dürtüye direnememe ile temsil edildiğini ve aynı zamanda bu satın alma eylemleri üzerindeki kontrol kaybıyla da karakterize edildiğini göstermiştir (Maccarrone-Eaglen ve Schofield, 2017, s. 463).

Genellikle kişinin fark edemediği ve kontrol dışında olan çeşitli psikolojik faktörlerin yön verdiği bu satın alma davranışında benlik kaygısı, imaj yaratma düşüncesi, saygınlık görme isteği, bireylerle ilişki kurma arayışı, güç ve statü talebi gibi etkenler kişileri alışveriş yapmaya sevk etmektedir. Bu gibi sebepler sonucunda ortaya çıan bu davranışın çoğunlukla, gereksinimi karşılama düşüncesinden çok, tutku ve bağımlılık yaratan bir durumun yansıması olduğu söylenebilir. Tüketicilerin bu şekildeki satın alma davranışları, içerisinde bir takım psikolojik süreçleri de barındırır (Kaderli vd., 2017, s. 190). Kompulsif tüketim içerisinde önemli bir yer tutan bu satın alma şeklini gösteren bireylerin, yaptıkları alışverişlerde plansız, anlık karar veren, harcamalarının parasal tutarını hesaplamakta zorluk yaşayan kişiler olduğu ifade edilebilir (Dittmar, 2004, s. 414).

Literatürde kompulsif satın alma davranışıyla aynı anlamda kullanılan tekrarlı satın alma, takıntılı satın alma, zorlayıcı satın alma, dürtüsel satın alma, kompulsif alışveriş gibi adlandırmalarda söz konusudur. Adlandırması değişse de kompulsif satın alma davranışını gösteren bireylerin satın almaktan zevk aldığı, satın almayı durduramadıkları, psikolojik olarak rahatladıkları için satın alımlar gerçekleştirdikleri, gereksiz ürünleri gereksiz miktarda satın aldıkları, satın alma davranışına bir tutku ve bağımlılık olarak baktıkları ifade edilebilir.

\section{Literatür taramas1}

İlgili literatürde etik tüketim, hedonik tüketim ve kompulsif satın alma davranışı konusunda yapılmış çalışmalardan birkaçı aşağıda verilmiştir.

Kushwah vd. (2019) tüketim değerleri teorisini kullanarak organik ürün alanlar ve almayanlar arasında etik tüketim niyetlerini ve seçim davranışını yönlendiren faktörleri incelemişlerdir. Çalışmada sosyal, duygusal ve epistemik değerlerin etik tüketim niyetleriyle anlamlı ilişkisini bulunmuştur. Epistemik değer, hem etik tüketime hem de seçim davranışına yönelik en önemli etken olarak belirlenmiştir. Organik ürün alanlar ve almayanlar arasında önemli bir farklılık görülmemiştir. Bununla birlikte, farklı düzeylerde çevresel kaygılara sahip tüketiciler, epistemik ve fiyatla ilgili işlevsel değerler ve etik tüketim niyetleri arasındaki ilişkiler söz konusu olduğunda istatistiksel olarak anlamlı farklılık gösterdiği de görülmüştür.

Alsaad (2021) tüketicilerin etik yargıları, niyetleri ve etik ürünlerin fiili satın alımları arasındaki ilişkilerin ahlaki kesinlik düzeylerine göre değişip değişmediğini ve öznel normların etkisini ampirik olarak incelediği çalışmasında tüketicilerin ahlaki belirsizliğe kıyasla, etik ürünleri satın almanın temelde doğru olduğuna ikna olduklarında, etik ürünlerin etik yargısının tüketicilerin niyeti üzerinde daha güçlü bir etkiye sahip olduğunu ortaya çıkarmıştır. Ayrıca öznel normların etkisinin, yüksek düzeyde ahlaki kesinlik altında daha az etkili çıktığı da bulunmuştur.

Başaran ve Büyükyılmaz (2015) fast-food ve fast-casual restoran sektörlerinde genç tüketicilerin memnuniyeti ve davranışsal niyetleri üzerindeki faydacı ve hedonik değerlerin etkilerini karşılaştırmalı olarak incelemişlerdir. Ayrıca faydacı veya hedonik bileşeninin hangisinin memnuniyet ve davranışsal niyetler üzerinde daha etkili olduğunu da araştırmışlardır. Çalışma da faydacı ve hedonik değerlerin hem fast-food hem de fast-casual restoran sektörleri için memnuniyet ve davranışsal niyetler üzerinde önemli etkileri olduğu görülmüştür. Ek olarak, memnuniyet, fastfood restoran sektöründe davranışsal niyetler üzerinde bir etkiye sahipken ancak fast-casual restoran 
sektöründe önemli bir etkiye sahip olmadığı ve yine hedonik değer ile memnuniyet ve davranışsal niyetler arasındaki ilişkilerin, fast-food ve fast-casual restoran sektörleri arasında önemli ölçüde farklılaştı̆̆ da bulunmuştur.

Hepolo vd. (2020) hizmet sürekliliği niyetine ilişkin tüketici katılımının açıklayıcı gücünü faydacı ve hedonik tutum ile memnuniyet değişkenleriyle karşılaştırdığı çalışmada hizmetin faydacı nedenlerle kullanıldığı durumlarda tüketici katılımına kıyasla tutum ve memnuniyetin hizmet sürekliliği niyetinin daha üstün itici güçleri olduğunu göstermektedir. Aksine, hizmet tüketimi hedonik nedenlerle yönlendirildiğinde, tüketici katılımı memnuniyetten daha güçlü bir itici güçtür. Bununla birlikte, hedonik bağlamda tüketici katılımının tutuma üstünlügüne dair hiçbir kanıt bulunamamıştır.

Phau ve Woo (2008) üniversite öğrencileri üzerinde yaptıkları çalışmada takıntılı tüketim davranışı gösteren tüketicilerin aşırı harcama yapmalarının parayı, güç ve statünün sembolü olarak görmelerinin neden olduğunu ifade etmiş̧lerdir.

Koru ve Kizman (2016) yaptıkları çalışmada kredi kartı kullanımının kompulsif satın almadaki rolüne odaklanmışlar ve kompulsif satın alma davranışının kredi kartı kötüye kullanımı ve satın alma sonrası pişmanlık ile pozitif ve anlamlı bir ilişkisinin olduğunu tespit etmişlerdir.

Kaderli vd. (2017) Y kuşağı üzerinde yaptıkları çalışmada Y kuşağındaki bireylerin paraya yönelik tutumu, kredi kartına yönelik tutumu ve materyalizm tutumunun kompulsif satın alma davranışı üzerinde etkili olduğu sonucuna ulaşılmışlardır.

Karahan ve Söylemez (2019) yaptıkları çalışmada materyalizm ve yaşıtların/akranların takıntılı tüketim davranışı üstünde etkisi olduğunu ancak öz saygının etkisinin olmadığını bulmuşlardır. Yine kompulsif satın alma davranışının tüketicilerin yaşadıkları satın alma sonrası pişmanlık üzerinde de etkisinin olduğu görülmüştür.

Karaboğa ve Pektaş (2020) X ve Y kuşakları üzerinde kompulsif satın alma davranışının alt boyutlarını farklılık gösterme durumunu incelemiş "Alışveriş Sonrası Suçluluk" ve "Haz ve Eğlence Odaklı Harcama" alt boyutlarının kuşaklara göre anlamlı farklılık göstermediğini; kompulsif satın alma boyutlarından "Harcama Eğilimi", "İşlevsel Olmayan Harcamalar" ve "Harcama Zorunluluğu" alt boyutlarının ise istatistiksel açıdan anlamlı farklılık gösterdiğini tespit etmişlerdir.

Literatürde doğrudan etik tüketimin hedonik tüketim ve kompulsif satın alma davranışı üzerindeki etkisini ölçen bir çalışmaya rastlanmamıştır. Bu anlamda bu çalışma ilgili literatürü zenginleştirerek katkı sağlamaktadır.

\section{Araştırmanın Yöntemi}

\section{Araştırmanın örneklemi}

Araştırmanın çalışma grubunu 18 yaşından büyük 564 kişi oluşturmaktadır. Çalışmada kullanılan veriler 25-28 Aralık 2020 tarihlerinde online anket yöntemi ile toplanmıştır. Sosyal medya ve mobil iletişim uygulamaları aracılığıyla anket linki paylaşılmıs ve katılımcılardan doldurulması istenmiştir. Çağriya olumlu dönüş yapan ve geçerli olan toplam 564 anket üzerinden verilerin analizi gerçekleştirilmiştir.

\section{Veri toplama aracı}

Çalışmada beşli Likert tipinde (1-Kesinlikle Katılmıyorum...3-Ne Katılıyorum Ne Katılmıyorum...5Kesinlikle Katılıyorum) toplam 28 adet ifadeden oluşan ölçüm aracı kullanılmıştır. Ölçekte yer alan Etik Tüketim ile ilgili on ifade Sudbury ve Kohlbacher (2015) tarafından geliştirilen ve Aygün (2018) tarafından Türkçe'ye uyarlanan Etik Tüketim Ölçeğinden, Hedonik Tüketim ile ilgili dokuz ifade Yaşar (2017)' in çalışmasından ve Kompulsif Satın Alma Davranışıyla ilgili dokuz ifade ise Valence vd. (1998) tarafından geliştirilen ve Kaderli vd. (2017) tarafından Türkçe' ye uyarlanan ölçekten alınmıştır. Ayrıca ölçüm aracında katılımcıların demografik özelliklerini ölçen yedi adet ifade daha vardır. Çalışmada zaman, maliyet ve pandemi koşulları nedeniyle çevrimiçi anket yöntemi tercih edilmiştir. 


\section{Araştırmanın modeli ve hipotezleri}

Araştırma modeli aşağıdaki Şekil 1'deki gibidir:

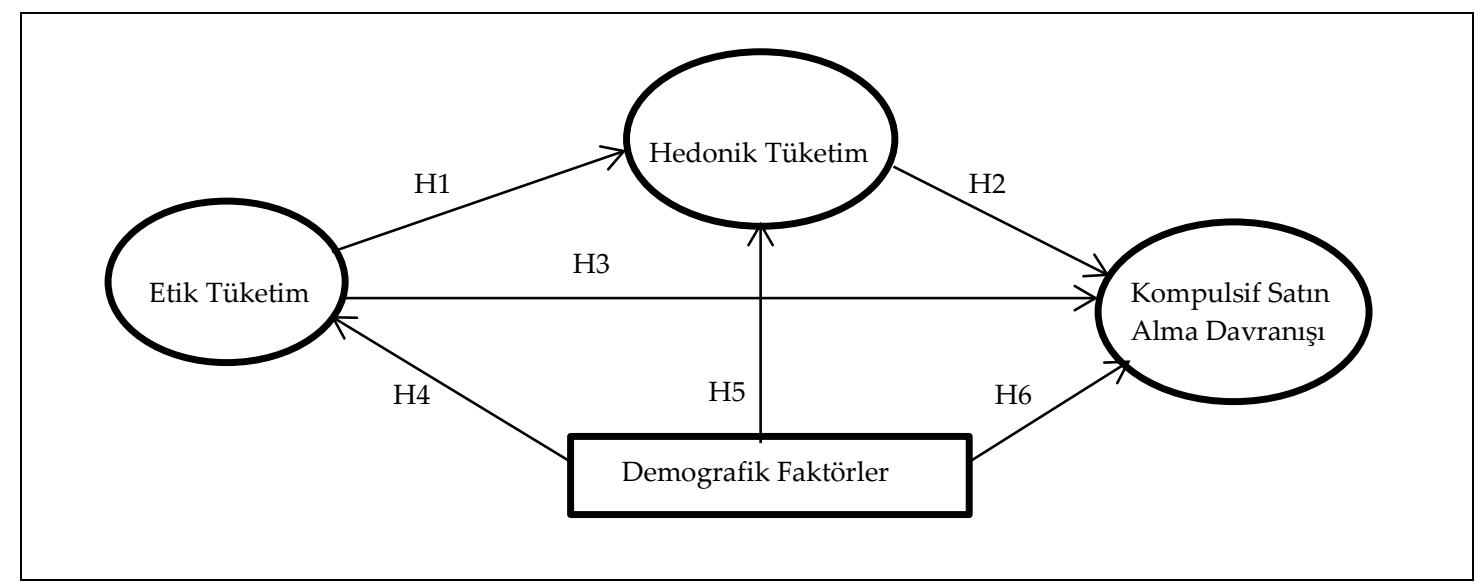

Şekil 1: Araştırmanın Modeli ve Hipotezleri

Kaynak: Yazar tarafından üretilmiştir.

Şekil 1'e göre Etik Tüketim bağımsız değişkeni, Hedonik Tüketim aracı değişkeni ve Kompulsif Satın Alma davranışı ise bağımlı değişkeni ifade etmektedir. Buna göre çalışmanın hipotezleri aşağıdaki gibi oluşturulmuştur:

H1: Etik Tüketimin Hedonik Tüketim üzerinde anlamlı bir etkisi vardır.

H2: Hedonik Tüketimin Kompulsif Satın Alma Davranışı üzerinde anlamlı bir etkisi vardır.

H3: Etik Tüketimin Kompulsif Satın Alma Davranışı üzerinde anlamlı bir etkisi vardır.

H4: Etik Tüketim katılımcıların demografik özelliklerine göre anlamlı bir farklılık göstermektedir.

H4.1: Etik Tüketim katılımcıların cinsiyetine göre anlamlı bir farklılık göstermektedir.

H4.2: Etik Tüketim katılımcıların yaşlarına göre anlamlı bir farklılık göstermektedir.

H4.3: Etik Tüketim katılımcıların eğitim durumlarına göre anlamlı bir farklılık göstermektedir.

H4.4: Etik Tüketim katılımcıların aylık ortalama gelirlerine göre anlamlı bir farklılık göstermektedir.

H4.5: Etik Tüketim katılımcıların medeni durumlarına göre anlamlı bir farklılık göstermektedir.

H4.6: Etik Tüketim katılımcıların mesleklerine göre anlamlı bir farklılık göstermektedir.

H4.7: Etik Tüketim katılımcıların yaşadıkları bölgeye göre anlamlı bir farklılık göstermektedir.

H5: Hedonik Tüketim katılımcıların demografik özelliklerine göre anlamlı bir farklılık göstermektedir.

H5.1: Hedonik Tüketim katılımcıların cinsiyetine göre anlamlı bir farklılık göstermektedir.

H5.2: Hedonik Tüketim katılımcıların yaşlarına göre anlamlı bir farklılık göstermektedir.

H5.3: Hedonik Tüketim katılımcıların eğitim durumlarına göre anlamlı bir farklılık göstermektedir.

H5.4: Hedonik Tüketim katılımcıların aylık ortalama gelirlerine göre anlamlı bir farklılık göstermektedir.

H5.5: Hedonik Tüketim katılımcıların medeni durumlarına göre anlamlı bir farklılık göstermektedir.

H5.6: Hedonik Tüketim katılımcıların mesleklerine göre anlamlı bir farklılık göstermektedir.

H5.7: Hedonik Tüketim katılımcıların yaşadıkları bölgeye göre anlamlı bir farklılık göstermektedir.

H6: Kompulsif Satın Alma Davranışı katılımcıların demografik özelliklerine göre anlamlı bir farklılık göstermektedir. 
H6.1: Kompulsif Satın Alma Davranışı katılımcıların cinsiyetine göre anlamlı bir farklılık göstermektedir.

H6.2: Kompulsif Satın Alma Davranışı katılımcıların yaşlarına göre anlamlı bir farklılık göstermektedir.

H6.3: Kompulsif Satın Alma Davranışı katılımcıların eğitim durumlarına göre anlamlı bir farklılık göstermektedir.

H6.4: Kompulsif Satın Alma Davranışı katılımcıların aylık ortalama gelirlerine göre anlamlı bir farklılık göstermektedir.

H6.5: Kompulsif Satın Alma Davranışı katılımcıların medeni durumlarına göre anlamlı bir farklılık göstermektedir.

H6.6: Kompulsif Satın Alma Davranışı katılımcıların mesleklerine göre anlamlı bir farklılık göstermektedir.

H6.7: Kompulsif Satın Alma Davranışı katılımcıların yaşadıkları bölgeye göre anlamlı bir farklılık göstermektedir.

\section{Kullanılan istatistiksel teknikler}

Çalışmada ilk olarak normal dağılım testi uygulanmış ve verilerin normal dağıldığı saptanmıştır. İkinci aşamada PLS-SEM ile Doğrulayıcı Faktör Analizi yapılmış ve ölçek geçerliliği ve güvenirliğine ilişkin bulgular ortaya konulmuştur. Üçüncü aşamada ise araştırma modeli Yol Analizi ile test edilmiş ve Etik Tüketimin Hedonik Tüketim ve Kompulsif Satın Alma Davranışı üzerindeki etkisi ortaya konulmuştur. Son aşamada ise faktörler katılımcıların eğitim, meslek, cinsiyet, yaş, gelir, medeni durum ve yaşadıkları bölgelere göre parametrik testler olan Bağımsız Örneklemler T Testi ve Tek Yönlü F Testi ile karşılaştırılmıştır. Ayrıca farklılık çıkan gruplar içinse Post-Hoc Çoklu Karşılaştırma Testlerinden Tukey ve Tamhanes'T2 testleri kullanılmıştır.

PLS-SEM yönteminde daha çok küçük örneklemler (30-100 arası) üzerinden analizin gerçekleştirilmesi önerilse de örneklemin sayısı ile ilgili kesin bir kural olmadığı da bilinmektedir (Chin ve Newsted, 1999, s. 314). Ancak örneklem sayısı 250 ve üzeri olduğunda ve doğru sayıda gösterge değişken varsa, her bir yapıyı ölçmek için kullanılan diğer yapısal eşitlik modelleriyle (CB-SEM: AMOS, LISREL vb.) PLS-SEM'in sonuçları neredeyse aynı doğruluktadır (Hair vd., 2016, s.45). Dolayısıyla bu çalışmada araştırma modelinin test edilmesinde PLS-SEM yöntemi tercih edilmiştir.

Verilerin analizinde SPSS 23.0 ve SMARTPLS 3.0 paket programları kullanılmıştır.

\section{Bulgular}

\section{Katılımcıların demografik özelliklerine ilişkin bulgular}

Çalışmaya katılan bireylere ait bulgular Tablo 1'de verilmiştir.

Tablo 1'e göre çalışmaya katılanların \%56,4'ü kadınlardan, \%43,6'sı ise erkeklerden oluşmaktadır. Yaş dağılımına bakıldığında en yükse katılım \%76,4 ile 18-25 yaş, en az katılım ise \%2,5 ile 50 yaş ve üzeri olan kişilerdedir. Eğitim seviyesine göre dağılıma bakıldığında en yüksek katılım \%41 ile Lisans, en az katılım ise \%3,4 ile Lisansüstü mezunlarındadır. Aylık ortalama aile geliri dağılımına bakıldığında en yüksek katılım \%43,8 ile 2500 TL ve altı, en düşük katılım ise \%8 ile 4501-5500 TL arası geliri olanlardadır. Meslek/çalışılan sektöre göre dağılıma bakıldığında en yüksek katılım \%58,5 ile öğrenci en az katılım ise \%1,2 ile emeklilerdedir. Yaşanılan bölgeye göre dağılıma bakıldığında en yüksek katılım \%31,7 ile İç Anadolu, en az katılım ise \%3,7 ile Ege ve Güneydoğu Anadolu bölgesinde yaşayanlardadır. Son olarak çalışmaya katılanların \%17,7'si evlilerden, \%81,2'si bekarlardan ve \%1,1'i ise diğer medeni duruma sahip kişilerden oluşmaktadır. 
Tablo 1: Katılcımcıların Demografik Özellikleri

\begin{tabular}{lcclcc}
\hline Cinsiyet & Frekans & $\mathbf{\%}$ & Medeni Durum & Frekans & \% \\
\hline Kadın & 318 & 56,4 & (1) Evli & 100 & 17,7 \\
Erkek & 246 & 43,6 & (2) Bekâr & 458 & 81,2 \\
Yaş & Frekans & \% & (3) Diğer & 6 & 1,1 \\
(1) $18-25$ & 431 & 76,4 & Meslek/Sektör & Frekans & $\%$ \\
(2) $26-33$ & 68 & 12,1 & (1) Kamu Sektörü & 56 & 9,9 \\
(3) $34-41$ & 19 & 3,4 & (2) Özel Sektör & 87 & 15,4 \\
(4) $42-49$ & 32 & 5,7 & (3) Ev Kadını & 35 & 6,2 \\
(5) 50 yaş ve üzeri & 14 & 2,5 & (4) Öğrenci & 330 & 58,5 \\
Eğitim Durumu & Frekans & \% & (5) Esnaf/Tüccar & 16 & 2,8 \\
(1) İlköğretim ve altı & 29 & 5,1 & (6) Emekli & 7 & 1,2 \\
(2) Lise & 163 & 28,9 & (7) Serbest Meslek & 33 & 5,9 \\
(3) Ön Lisans & 122 & 21,6 & Yaşanılan Bölge & Frekans & $\%$ \\
(4) Lisans & 231 & 41,0 & (1) Marmara & 92 & 16,3 \\
(5) Lisansüstü & 19 & 3,4 & (2) Ege & 21 & 3,7 \\
Ay. Ort. Aile Geliri & Frekans & $\%$ & (3) İç Anadolu & 179 & 31,7 \\
(1) 2500 TL ve altı & 247 & 43,8 & (4) Akdeniz & 42 & 7,4 \\
(2) 2501-3500 TL & 130 & 23,0 & (5) Karadeniz & 129 & 22,9 \\
(3) 3501-4500 TL & 74 & 13,1 & (6) Doğu Anadolu & 80 & 14,2 \\
(4) 4501-5500 TL & 45 & 8,0 & (7) G.Doğu Anadolu & 21 & 3,7 \\
(5) 5501 TL ve üstü & 68 & 12,1 & & 564 & $\mathbf{1 0 0}$ \\
Toplam & $\mathbf{5 6 4}$ & $\mathbf{1 0 0}$ & Toplam & &
\end{tabular}

Kaynak: Yazar tarafından üretilmiştir.

\section{Normal dağılıma ilişkin bulgular}

Araştırmada demografik değişkenlere gore karşılaştırmada kullanılacak analiz tekniklerini belirlemek amaciyla veriler normallik sınamasına tabi tutulmuştur. Yapılan Kolmogorov-Smirnov testinde verilerin normal dağılmadığı görülmüştür $(\mathrm{p}<0.05)$. Bu durumda faktörlerin ve maddelerin basıklık ve çarpıklık değerlerine bakılmıştır. Faktörlere ait betimleyici istatistikler aşağıdaki Tablo 2'de verilmiştir.

Tablo 2: Faktörlerin Tanımlayıcı İstatistikleri

\begin{tabular}{cccccccc}
\hline Faktörler & N & Ort. & ss. & Çarpk. & Bask. & Min & Maks \\
\hline Etik Tüketim & 564 & 3,3314 &, 91521 &,- 727 &, 103 & 1,00 & 5,00 \\
Hedonik Tüketim & 564 & 2,6474 &, 90787 &, 184 &,- 658 & 1,00 & 5,00 \\
Kompulsif Satın Alma & 564 & 2,2727 &, 87831 &, 821 &, 385 & 1,00 & 5,00 \\
\hline
\end{tabular}

Kaynak: Yazar tarafından üretilmiştir.

Likert Tipi ölçeklerde normallik varsayımı için bakılan diğer bir kriter ise çarpıklık ve basıklık katsayısı değerlerinin +1 ve -1 arasında olması gerektiğidir (Hair vd., 2016). Bu bağlamda Tablo 2'de verilen değerler faktörlerin istenilen aralıklarda puanlara sahip olduğunu ve verilerin normal dağılım gösterdiğini göstermektedir. Normal dağılım varsayımı sağlandığından verilerin analizlerinde parametrik testler kullanılmıştır.

\section{Doğrulayıcı faktör analizine ilişkin bulgular}

PLS-SEM ile model ilk olarak doğrulayıcı faktör analizine tabi tutulmuş ve faktörlerin AVE, CR, rho_A, Cronbach Alpha ve ayrışma geçerliliğine (Fornell-Larcker Kriter Katsayısı ve HeterotraitMonotrait Oranı Katsayıları) bakılmıştır. CR değerlerinin 0,7 ve üzeri; AVE değerlerinin 0,5 üzeri ve tüm CR değerlerinin de AVE değerlerinden büyük olması halinde ölçeğin yakınsak ve uyum geçerliliğini sağladığı ifade edilebilir (Yaşlığlu, 2017, s. 82). Cronbach $\alpha$ katsayısının ise 0.60-0.79 arasında değer alması ölçeğin "oldukça güvenilir", 0.80-1.00 arasında olması ölçeğin "yüksek güvenilirlikte" olduğunu ifade etmektedir (Tavşancıl, 2014, s. 29). rho_A (Veri Tutarlılık Katsayısı)'nın da 0,70 ve üzeri olması halinde faktör öğeleri güvenilirdir denilebilir (Hair vd., 2016). Faktörlere ve ölçeğin tamamına geçerlilik ve güvenirlik katsayıları Tablo 3'deki gibi bulunmuştur. 
Tablo 3: Ölçeklerin Geçerliliği ve Güvenirlik Katsayıları

\begin{tabular}{ccccc}
\hline Faktörler & Cronbach's Alpha & rho_A & $\begin{array}{c}\text { Birleşik Güvenirlik } \\
\text { Katsayısı (CR) }\end{array}$ & $\begin{array}{c}\text { Çıarılan Ortak } \\
\text { Varyans (AVE) }\end{array}$ \\
\hline Etik Tüketim & 0,908 & 0,911 & 0,924 & 0,548 \\
Hedonik Tüketim & 0,869 & 0,880 & 0,896 & 0,493 \\
Kompulsif Satın Alma & 0,896 & 0,903 & 0,915 & 0,547 \\
\hline
\end{tabular}

Kaynak: Yazar tarafından üretilmiştir.

Tablo 3'deki sonuçlara göre ölçekte yer alan üç faktöründe CR değerlerinin 0,7 ve üzerinde olduğu; AVE değerlerinin Hedonik Tüketim faktörü haricinde 0,5 ve üzerinde olduğu ve son olarak tüm CR değerlerinin AVE değerlerinden büyük olduğu görülmektedir. Buna göre ölçek uyum ve yakınsak geçerliliğini sağlamaktadır denilebilir.

Yine Tablo 3'e göre Etik Tüketim faktörünün Cronbach $\alpha$ katsayısı 0,908, Hedonik Tüketim faktörünün 0,859 ve Kompulsif Satın Alma Davranışı faktörünün 0,896 bulunmuştur. Ayrıca ölçeğin tümüne ait Cronbach $\alpha$ ise 0,919 olarak bulunmuştur. Yine rho_A katsayılarının tamamı da 0,7'nin üzerindedir. Buna göre tüm faktörler ve ölçeğin tamamı yüksek güvenirliliğe sahiptir. Dolayısıyla araştırmada kullanılan ölçeğin aynı zamanda güvenilir olduğu da görülmektedir.

Ayrışma geçerliliği için Fornell ve Larcker (1981) tarafından önerilen Fornell-Larcker kriterleri ile Henseler vd. (2015) tarafından önerilen Heterotrait-Monotrait oranı katsayılarına bakılmıştır. İlgili istatistiklere ilişkin bulgular ise aşağıdaki Tablo 4'teki gibidir.

Tablo 4: Ayrışma Geçerliliği Katsayıları

\begin{tabular}{|c|c|c|c|c|c|c|c|}
\hline \multicolumn{4}{|c|}{ Fornell-Larcker Kriter Katsayıları } & \multicolumn{4}{|c|}{ Heterotrait-Monotrait Oran Katsayıları } \\
\hline Faktörler & ET & HT & KSA & Faktörler & ET & HT & KSA \\
\hline Etik Tüketim &, $740^{*}$ & & & Etik Tüketim & & & \\
\hline Hedonik Tüketim &, $364^{* *}$ &, $702^{*}$ & & Hedonik Tüketim & ,405 & & \\
\hline Kompulsif Satın Alma &, $213^{* *}$ & $672^{* *}$ & ,739* & Kompulsif Satın Alma & ,223 & ,742 & \\
\hline
\end{tabular}

Fornell ve Larcker kriterinde AVE değerlerinin kareköklerinin faktörler arasındaki korelasyon katsayılarından yüksek olması gerekir (Fornell ve Larcker, 1981). Heterotrait-Monotrait oranı ise modelde yer alan faktöre ait korelasyon ortalamasının yine aynı faktöre ait korelasyon katsayının geometrik ortalamasına oranıdır ve oranın 0,85`den küçük olması beklenir (Henseler vd.,2015). Buna göre Tablo 4'e göre tüm faktörler ayrışma geçerliliğini sağlamaktadır. Ayrıca Korelasyon katsayısının 0,30'dan küçük olması "zayıf" ; 0,30-0,40 arası "nispeten zayıf" ve 0,61-0,70 arası olması ise "nispeten güçlü" olarak ifade edilebilir (Nakip, 2013, s. 427). Buna göre Etik Tüketim ile Hedonik Tüketim arasında pozitif yönlü yaklaşık \%36 oranında nispeten zayıf bir ilişki vardır. Yine Etik Tüketim ile Kompulsif Satın Alma Davranışı arasında pozitif yönlü yaklaşık \%21 oranında zayıf düzeyde bir ilişki vardır. Son olarak Hedonik Tüketim ile Kompulsif Satın Alma Davranışı arasında pozitif yönlü yaklaşık \%67 oranında nispeten güçlü düzeyde bir ilişki vardır.

Ölçek geçerliliği ve güvenirliği için bakılan CR, AVE, rho_A, Cronbach Alpha, Fornell-Lacker ve Heterotrait-Monotrait Oran Katsayıları literatürde kabul edilen aralıklarda olduğu için araştırmada kullanılan ölçeğinde geçerli ve güvenilir olduğu görülmüştür.

\section{Yol analizine ilişkin bulgular}

PLS-SEM ile çizilen araştırma modelinin diyagramı Şekil 2'de verilmiştir. 


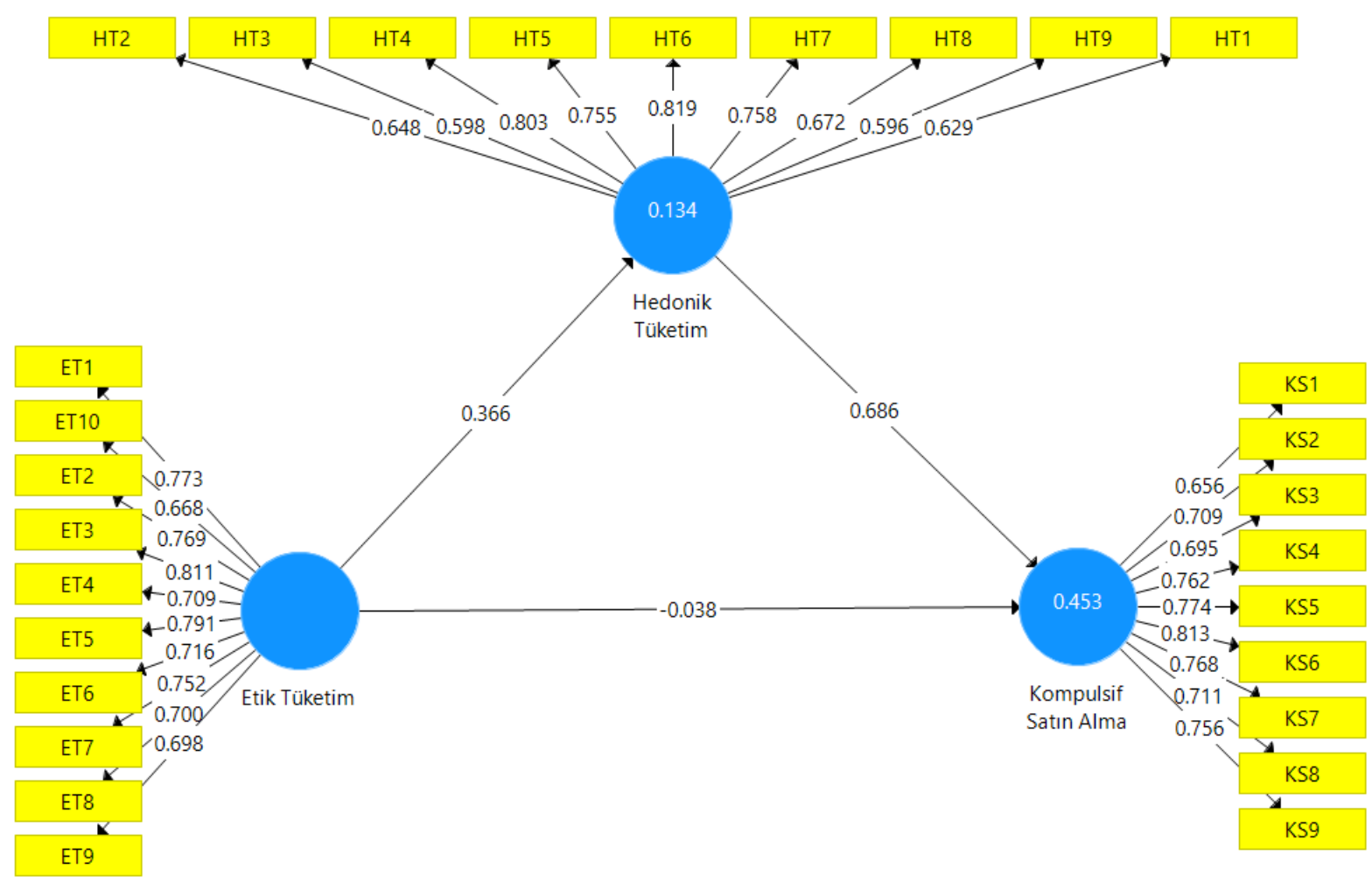

Şekil 2: Araştırma Modelinin Yol Şeması

Kaynak: Yazar tarafından üretilmiştir.

Şekil 2'de verilen araştırma modelinin PLS-SEM ile test edilmesi sonucunda Etik Tüketimin Hedonik Tüketimi pozitif ve yaklaşık $\% 13$ oranında etkilediği görülmektedir $\left(\beta=0,366 ; \mathrm{R}^{2}=0,134\right)$. Yine Etik Tüketim Kompulsif Satın Alma Davranışını negatif ve yaklaşık \%4 oranında etkilemektedir $(\beta=-0,038$; $\left.R^{2}=-0,038\right)$. Son olarak Hedonik Tüketim Kompulsif Satın Alma Davranışını pozitif ve yaklaşık \%69 oraninda etkilemektedir $\left(\beta=0,686 ; R^{2}=0,453\right)$. PLS-SEM' de 5000 birimlik bootstrap uygulanarak modeldeki yolların anlamlılı̆̆ı test edilmiştir. Buna göre modelde yer alan yol katsayılarının anlamlılığı aşağıdaki Tablo 5'de verilmiştir.

Tablo 5: Yol Katsayılarının Anlamlılı̆̆1

\begin{tabular}{lccccc}
\hline \multicolumn{1}{c}{ Yollar } & $\begin{array}{c}\text { Orijinal } \\
\text { Orneklem } \\
(\mathbf{O})\end{array}$ & $\begin{array}{c}\text { Örneklem } \\
\text { Ortalamasi } \\
(\mathbf{M})\end{array}$ & $\begin{array}{c}\text { Standart } \\
\text { Sapma } \\
\text { (STDEV) }\end{array}$ & $\begin{array}{c}\text { T İstatistiği } \\
(\mid \mathbf{O} / \text { STDEVI) }\end{array}$ & P Değerleri \\
\hline H1:Etik Tüketim -> Hedonik Tüketim & 0,366 & 0,369 & 0,041 & 8,899 & $\mathbf{0 , 0 0 0}$ \\
H2:Hedonik Tüketim -> Kompulsif Satın Alma & 0,686 & 0,690 & 0,033 & 20,932 & $\mathbf{0 , 0 0 0}$ \\
H3:Etik Tüketim -> Kompulsif Satın Alma & $-0,038$ & $-0,038$ & 0,037 & 1,032 & $\mathbf{0 , 3 0 3}$ \\
\hline
\end{tabular}

Kaynak: Yazar tarafından üretilmiştir.

PLS-SEM'de yol katsayılarının anlamlı olabilmesi için $t$ değerlerinin 1,96'dan büyük olması gerekir. Tablo 5'e göre modelde yer alan Etik Tüketim -> Hedonik Tüketim ve Hedonik Tüketim -> Kompulsif Satın Alma Davranışı yollarının t değerleri 1,96'dan büyük olduğu için istatistiksel olarak anlamlıdır ve H1 ile H2 kabul edilmiştir. Ancak Etik Tüketim -> Kompulsif Satın Alma Davranışına giden yolun katsayısı 1,96'dan küçük olduğu için anlamsızdır. Bu bağlamda etik tüketimin kompulsif satın alma davranışı üzerinde doğrudan bir etkisinin olmadığı görülmüştür ve H3 reddedilmiştir. Ancak PLSSEM'de dolaylı etkilerde görülebilmektedir. Buna göre Etik Tüketim'in Kompulsif Satın Alma Davranışı Üzerindeki (Etik Tüketim -> Hedonik Tüketim $\rightarrow$ Kompulsif Satın Alma, $\beta=0,251 ; t=7,620$, $\mathrm{p}<0,05)$ dolaylı etkisinin anlamlı olduğu bulunmuştur. Ve etik tüketim kompulsif satın alma davranışını dolaylı olarak \%25 oranında etkilemektedir.

PLS-SEM'de kurulan modelin anlamlılı̆̆ını test etmede SRMR, NFI ve $\chi 2$ değerleri olacak şekilde üç farklı uyum indeksi kullanılır (Hair vd., 2016). SRMR $<0.08$ ve NFI $>0,90$ olması gerekmektedir. Bu bağlamda araştırma modelinin uyum iyiliği skorlarından SRMR $=0,068 ; N F I=0,911$ ve $\chi 2=1713,072$ 
bulunmuştur. Bu skorlara göre modelin iyi uyum gösterdiği söylenebilir. Dolayısıyla araştırmacı tarafından kurulan model istatistiksel olarak anlamlı ve geçerlidir denebilir.

\section{Bağımsız örneklemler $t$ testine ait bulgular}

\section{Faktörlerin cinsiyete göre karşılaştırılması}

Üç faktöründe Levene homojenlik testine göre homojen olduğu görülmüştür $(p>0,05)$. Cinsiyete göre yapılan karşılaştırma sonuçları aşağıdaki Tablo 6' dadır.

Tablo 6: Cinsiyete Göre Faktörlerin Karşılaştırması

\begin{tabular}{|c|c|c|c|c|c|c|}
\hline Faktörler & Cinsiyet & $\mathbf{n}$ & Ortalama & Std Sap. & $t$ & $\mathbf{p}$ \\
\hline \multirow{2}{*}{ Etik Tüketim } & Kadın & 318 & 2,7876 & ,91368 & \multirow{2}{*}{ 744 } & \multirow{2}{*}{, 457} \\
\hline & Erkek & 246 & 2,4661 & 86913 & & \\
\hline \multirow{2}{*}{ Hedonik Tüketim } & Kadın & 318 & 3,3566 & ,85700 & \multirow{2}{*}{4,232} & \multirow{2}{*}{, 000} \\
\hline & Erkek & 246 & 3,2988 & ,98621 & & \\
\hline \multirow{2}{*}{$\begin{array}{l}\text { Kompulsif Satın } \\
\text { Alma Davranışı }\end{array}$} & Kadın & 318 & 2,4214 & 87636 & \multirow{2}{*}{4,655} & \multirow{2}{*}{,000 } \\
\hline & Erkek & 246 & 2,0804 & 84450 & & \\
\hline
\end{tabular}

Kaynak: Yazar tarafından üretilmiştir.

Tablo 6'ya göre Etik Tüketim cinsiyete göre değişmemektedir ve H4.1 reddedilmiştir (p>0,05). Ancak Hedonik Tüketim ve Kompulsif Satın Alma Davranışı ise cinsiyete göre değişmektedir ve H5.1 ile H6.1 kabul edilmiştir $(\mathrm{p}<0,05)$. Ortalamalara bakıldığında her iki faktörde de kadın tüketicilerin erkek tüketicilerden ortalaması daha yüksektir. Buna göre kadınların daha fazla hedonik tüketim eğilimi ve daha fazla kompulsif satın alma davranışı gösterdiği söylenebilir. Etik tüketim açısından ise cinsiyetin farklılık yaratan bir unsur olmadığı söylenebilir.

\section{Tek yönlü anova testine ilişkin bulgular}

Faktörlerin tüketicilerin aylık ortalama gelir, yaş, eğitim durumu, meslek, medeni durum ve yaşadıkları bölgelere göre karşılaştırılmasında Tek Yönlü ANOVA Testi kullanılmıştır.

\section{Faktörlerin yaşa göre karşılaştırılması}

Tek Yönlü ANOVA ile Üç faktörün katılımcıların yaşlarına göre değişip değişmediği test edilmiştir. Sonuçlar aşağıdaki Tablo 7'de verilmiştir.

Tablo 7: Yaşa Göre Karşılaştırma Sonuçları

\begin{tabular}{|c|c|c|c|c|c|c|}
\hline Faktörler & Varyans Kaynağı & $\begin{array}{l}\text { Kareler } \\
\text { Toplamı }\end{array}$ & SD & Kareler Ort. & $\mathbf{F}$ & $\mathbf{p}$ \\
\hline \multirow{3}{*}{ Etik Tüketim } & Gruplar Arası & 3,945 & 4 & ,986 & \multirow{3}{*}{1,179} & \multirow{3}{*}{,319 } \\
\hline & Gruplar İçi & 467,630 & 559 & 837 & & \\
\hline & Toplam & 471,575 & 563 & & & \\
\hline \multirow{3}{*}{ Hedonik Tüketim } & Gruplar Arası & 6,375 & 4 & 1,594 & \multirow{3}{*}{1,947} & \multirow{3}{*}{,101 } \\
\hline & Gruplar İçi & 457,662 & 559 & 819 & & \\
\hline & Toplam & 464,037 & 563 & & & \\
\hline \multirow{3}{*}{$\begin{array}{c}\text { Kompulsif Satın Alma } \\
\text { Davranışı }\end{array}$} & Gruplar Arası & 4,341 & 4 & 1,085 & \multirow{3}{*}{1,411} & \multirow{3}{*}{229} \\
\hline & Gruplar İçi & 429,977 & 559 & ,769 & & \\
\hline & Toplam & 434,319 & 563 & & & \\
\hline
\end{tabular}

Kaynak: Yazar tarafından üretilmiştir.

Tablo 7'ye göre faktörlerin hiçbirisi katılımcıların yaşlarına göre değişmemektedir ve dolayısıyla H4.2, H5.2 ve H6.2 reddedilmiştir ( $>0,05)$. Buna göre yaşın Etik Tüketim, Hedonik Tüketim ve Kompulsif Satın Alma Davranışı bağlamında bir farklılığa neden olmadığı, yaşın büyük ya da küçük olmasının tüketicilerin etik tüketim ve hedonik tüketime bakış açlarını değiştirmediği ve kompulsif satın almada davranış farklılığı ortaya koymadığı ifade edilebilir.

\section{Faktörlerin eğitim durumuna göre karşılaştırılması}

Tek Yönlü ANOVA aracılığıyla Üç faktörün katılımcıların eğitim durumlarına göre değişip değişmediği test edilmiştir. Sonuçlar aşağıdaki Tablo 8'de verilmiştir. 
Tablo 8: Eğitim Durumlarına Göre Karşılaştırma Sonuçları

\begin{tabular}{|c|c|c|c|c|c|c|c|}
\hline Faktörler & Varyans Kaynağ1 & $\begin{array}{c}\text { Kareler } \\
\text { Toplamı }\end{array}$ & SD & Kareler Ort. & $\mathbf{F}$ & $\mathbf{p}$ & $\begin{array}{c}\text { Fark Çıkan } \\
\text { Gruplar }\end{array}$ \\
\hline \multirow{3}{*}{ Etik Tüketim } & Gruplar Arası & 2,575 & 4 & 644 & \multirow{3}{*}{,767 } & \multirow{3}{*}{, 547} & \\
\hline & Gruplar İçi & 469,000 & 559 & 839 & & & \\
\hline & Toplam & 471,575 & 563 & & & & \\
\hline \multirow{3}{*}{ Hedonik Tüketim } & Gruplar Arası & 11,521 & 4 & 2,880 & \multirow{3}{*}{3,558} & \multirow{3}{*}{, 007} & \multirow{3}{*}{$4-2$} \\
\hline & Gruplar İçi & 452,515 & 559 & 810 & & & \\
\hline & Toplam & 464,037 & 563 & & & & \\
\hline \multirow{3}{*}{$\begin{array}{c}\text { Kompulsif Satın Alma } \\
\text { Davranışı }\end{array}$} & Gruplar Arası & 10,904 & 4 & 2,726 & \multirow{3}{*}{3,599} & \multirow{3}{*}{, 007} & \multirow{3}{*}{$4-2$} \\
\hline & Gruplar İçi & 423,415 & 559 & ,757 & & & \\
\hline & Toplam & 434,319 & 563 & & & & \\
\hline
\end{tabular}

Kaynak: Yazar tarafından üretilmiştir.

Tablo 8'e göre Etik Tüketim eğitim durumuna göre farklılık göstermemektedir ve H4.3 reddedilmiştir $(\mathrm{p}>0,05)$. Ancak Hedonik Tüketim ve Kompulsif Satın Alma Davranışı anlamlı farklılık göstermektedir ve H5.3 ile H6.3 kabul edilmiştir $(\mathrm{p}<0,05)$. Hedonik Tüketim faktörünün varyansı homojen olduğu için kullanılan Tukey test sonucuna göre Üniversite mezun olanların ortalamasının Lise mezunlarına göre daha yüksek olduğu görülmüştür. Buna göre üniversite mezunlarının daha fazla hedonik tüketim eğilimi gösterdiği söylenebilir. Kompulsif Satın Alma Davranışı faktörünün varyansı homojen olmadığı için kullanılan Tamhanes'T2 test sonuçlarına göre de Üniversite mezun olanların ortalamasının Lise mezunlarına göre daha yüksek olduğu görülmüştür. Burada da üniversite mezunlarının daha fazla kompulsif satın alma eğilimi gösterdiği söylenebilir.

\section{Faktörlerin aylık ortalama gelire göre karşılaştırılması}

Üç faktörün katılımcıların aylık ortalama gelirlerine göre değişip değişmediği Tek Yönlü ANOVA aracılı̆̆ıyla test edilmiştir. Sonuçlar aşağıdaki Tablo 9'da verilmiştir.

Tablo 9: Aylık Ortalama Gelire Göre Karşılaştırma Sonuçları

\begin{tabular}{|c|c|c|c|c|c|c|c|}
\hline Faktörler & Varyans Kaynağı & $\begin{array}{l}\text { Kareler } \\
\text { Toplamı }\end{array}$ & SD & Kareler Ort. & $\mathbf{F}$ & $\mathrm{p}$ & $\begin{array}{c}\text { Fark Çıkan } \\
\text { Gruplar }\end{array}$ \\
\hline \multirow{3}{*}{ Etik Tüketim } & Gruplar Arası & 5,263 & 4 & 1,316 & \multirow{3}{*}{1,577} & \multirow{3}{*}{,179 } & \\
\hline & Gruplar İçi & 466,311 & 559 & 834 & & & \\
\hline & Toplam & 471,575 & 563 & & & & \\
\hline \multirow{3}{*}{ Hedonik Tüketim } & Gruplar Arası & 15,839 & 4 & 3,960 & \multirow{3}{*}{4,939} & \multirow{3}{*}{,001 } & \\
\hline & Gruplar İçi & 448,198 & 559 & ,802 & & & $\begin{array}{l}4-1 \\
5-1\end{array}$ \\
\hline & Toplam & 464,037 & 563 & & & & $5-1$ \\
\hline \multirow{3}{*}{$\begin{array}{c}\text { Kompulsif Satın Alma } \\
\text { Davranışı }\end{array}$} & Gruplar Arası & 14,656 & 4 & 3,664 & \multirow{3}{*}{4,881} & \multirow{3}{*}{,001 } & \multirow{3}{*}{$4-1$} \\
\hline & Gruplar İçi & 419,663 & 559 & ,751 & & & \\
\hline & Toplam & 434,319 & 563 & & & & \\
\hline
\end{tabular}

Kaynak: Yazar tarafından üretilmiştir.

Tablo 9'a göre Etik Tüketim gelir durumuna göre farklıllk göstermemektedir ve H4.4 reddedilmiştir $(p>0,05)$. Ancak Hedonik Tüketim ve Kompulsif Satın Alma Davranışı anlamlı bir farklılık göstermektedir ve H5.4 ile H6.4 kabul edilmiştir $(p<0,05)$. Hedonik Tüketim ve Kompulsif Satın Alma Davranışı faktörlerinin varyansları homojen olduğu için Tukey testi kullanılmıştır. Hedonik Tüketim faktöründe "4501-5500 TL" ve "5501 TL ve üstü" gruplarının ortalaması "2500 TL ve altı" olanlara göre daha yüksektir. Yine Kompulsif Satın Alma Davranışı faktöründe "4501-5500 TL" grubunun ortalaması "2500 TL ve altı" olanlara göre daha yüksektir. Her iki faktörde de geliri yüksek olanların daha fazla hedonik tüketim eğilimi ve kompulsif satın alma davranışı gösterdiği görülmektedir. Buna göre gelir arttıkça hedonik amaçlarla tüketmek ve anlık satın alma kararı vermek daha olasıdır. Gelir azaldıkça da tam aksi durum geçerlidir denebilir.

Faktörlerin medeni duruma göre karşılaştırılması

Tek Yönlü ANOVA aracıllğıyla üç faktörün katılımcıların medeni durumlarına göre değişip değişmediği test edilmiştir. Sonuçlar aşağıdaki Tablo 10'da verilmiştir. 
Tablo 10: Medeni Duruma Göre Karşılaştırma Sonuçları

\begin{tabular}{|c|c|c|c|c|c|c|c|}
\hline Faktörler & Varyans Kaynağı & $\begin{array}{l}\text { Kareler } \\
\text { Toplamı }\end{array}$ & SD & Kareler Ort. & $\mathbf{F}$ & $\mathbf{p}$ & $\begin{array}{c}\text { Fark Çıkan } \\
\text { Gruplar }\end{array}$ \\
\hline \multirow{3}{*}{ Etik Tüketim } & Gruplar Arası & 622 & 2 & 311 & \multirow{3}{*}{, 370} & \multirow{3}{*}{,691 } & \\
\hline & Gruplar İçi & 470,953 & 561 & 839 & & & \\
\hline & Toplam & 471,575 & 563 & & & & \\
\hline \multirow{3}{*}{ Hedonik Tüketim } & Gruplar Arası & 10,201 & 2 & 5,100 & \multirow{3}{*}{6,305} & \multirow{3}{*}{,002 } & \\
\hline & Gruplar İçi & 453,836 & 561 & 809 & & & $2-1$ \\
\hline & Toplam & 464,037 & 563 & & & & $2-3$ \\
\hline \multirow{3}{*}{$\begin{array}{c}\text { Kompulsif Satın Alma } \\
\text { Davranışı }\end{array}$} & Gruplar Arası & 4,355 & 2 & 2,177 & \multirow{3}{*}{2,841} & \multirow{3}{*}{,059 } & \\
\hline & Gruplar İçi & 429,964 & 561 & ,766 & & & \\
\hline & Toplam & 434,319 & 563 & & & & \\
\hline
\end{tabular}

Kaynak: Yazar tarafından üretilmiştir.

Tablo 10'a göre Etik Tüketim ve Kompulsif Satın Alma Davranışı faktörleri katılımcıların medeni durumlarına göre değişmemektedir ve H4.5 ile H6.5 reddedilmiştir ( $>>0,05)$. Ancak Hedonik Tüketim anlamlı bir farklılık göstermektedir ve H5.5 kabul edilmiştir $(\mathrm{p}<0,05)$. Hedonik Tüketim faktörünün Tukey testi sonucuna göre "Bekar" olanların ortalaması "Evli" ve "Diğer" grubundakilere göre daha yüksektir. Buna göre bekar olan tüketicilerin daha fazla hedonik tüketim eğilimi gösterdiği ifade edilebilir.

\section{Faktörlerin meslek/çalışılan sektöre göre karşılaştırılması}

Üç faktörün katılımcıların mesleklerine/çalıştıkları sektörlere göre değişip değişmediği Tek Yönlü ANOVA aracılığıyla test edilmiştir. Sonuçlar aşağıdaki Tablo 11'de verilmiştir.

Tablo 11'e göre Etik Tüketim meslek türüne göre farklılık göstermemektedir ve H4.6 reddedilmiştir $(p>0,05)$. Ancak Hedonik Tüketim ve Kompulsif Satın Alma Davranışı anlamlı bir farklılık göstermektedir ve H5.6 ile H6.6 kabul edilmiştir $(\mathrm{p}<0,05)$. Hedonik Tüketim faktörünün varyansı homojen olduğu için kullanılan Tukey test sonucuna göre "Öğrenci" olanların ortalamasının "Kamu Sektörü" çalışanlarına göre daha yüksek olduğu görülmüştür. Buna göre öğrencilerin daha fazla hedonik tüketim eğilimi gösterdiği söylenebilir. Kompulsif Satın Alma Davranışı faktörünün varyansı homojen olmadığı için kullanılan Tamhanes'T2 test sonuçlarına göre ise "Özel Sektör", "Öğrenci" ve "Ev Kadını" olanların ortalamasının "Kamu Sektörü" çalışanlarına göre daha yüksek olduğu görülmüştür. Her iki faktörde de kamu sektörü çalışanlarının daha az hedonik tüketim eğilimi ve kompulsif satın alma davranışı gösterdiği söylenebilir. Yine öğrencilerin diğer mesleklere göre hem hedonik tüketim eğilimi hem de kompulsif satın alma davranışını daha fazla gösterdiği de ifade edilebilir.

Tablo 11: Mesleklere Göre Karşılaştırma Sonuçları

\begin{tabular}{|c|c|c|c|c|c|c|c|}
\hline Faktörler & Varyans Kaynağ1 & $\begin{array}{l}\text { Kareler } \\
\text { Toplamı }\end{array}$ & SD & Kareler Ort. & $\mathbf{F}$ & $\mathbf{p}$ & $\begin{array}{c}\text { Fark Çıkan } \\
\text { Gruplar }\end{array}$ \\
\hline \multirow{3}{*}{ Etik Tüketim } & Gruplar Arası & 7,672 & 6 & 1,279 & \multirow{3}{*}{1,535} & \multirow{3}{*}{ 164 } & \\
\hline & Gruplar İçi & 463,903 & 557 & 833 & & & \\
\hline & Toplam & 471,575 & 563 & & & & \\
\hline \multirow{3}{*}{ Hedonik Tüketim } & Gruplar Arası & 18,856 & 6 & 3,143 & \multirow{3}{*}{3,932} & \multirow{3}{*}{,001 } & \multirow{3}{*}{$4-1$} \\
\hline & Gruplar İçi & 445,181 & 557 & ,799 & & & \\
\hline & Toplam & 464,037 & 563 & & & & \\
\hline \multirow{3}{*}{$\begin{array}{c}\text { Kompulsif Satın Alma } \\
\text { Davranışı }\end{array}$} & Gruplar Arası & 20,697 & 6 & 3,449 & \multirow{3}{*}{4,645} & \multirow{3}{*}{, 000} & $2-1$ \\
\hline & Gruplar İçi & 413,622 & 557 & ,743 & & & $3-1$ \\
\hline & Toplam & 434,319 & 563 & & & & 4-1 \\
\hline
\end{tabular}

Kaynak: Yazar tarafından üretilmiştir.

\section{Faktörlerin yaşanılan bölgelere göre karşılaştırılması}

Üç faktörün katılımcıların yaşadıkları bölgelere göre değişip değişmediği Tek Yönlü ANOVA aracılığıyla test edilmiştir. Sonuçlar aşağıdaki Tablo 12'de verilmiştir. 
Tablo 12: Bölgelere Göre Karşılaştırma Sonuçları

\begin{tabular}{|c|c|c|c|c|c|c|c|}
\hline Faktörler & Varyans Kaynağ1 & $\begin{array}{l}\text { Kareler } \\
\text { Toplamı }\end{array}$ & SD & Kareler Ort. & $\mathbf{F}$ & $\mathbf{p}$ & $\begin{array}{c}\text { Fark Çıkan } \\
\text { Gruplar }\end{array}$ \\
\hline \multirow{3}{*}{ Etik Tüketim } & Gruplar Arası & 5,814 & 6 & 969 & \multirow{3}{*}{1,159} & \multirow{3}{*}{,327 } & \\
\hline & Gruplar İçi & 465,761 & 557 & 836 & & & \\
\hline & Toplam & 471,575 & 563 & & & & \\
\hline \multirow{3}{*}{ Hedonik Tüketim } & Gruplar Arası & 11,401 & 6 & 1,900 & \multirow{3}{*}{2,338} & \multirow{3}{*}{,031 } & \multirow{3}{*}{$5-6$} \\
\hline & Gruplar İçi & 452,636 & 557 & 813 & & & \\
\hline & Toplam & 464,037 & 563 & & & & \\
\hline \multirow{3}{*}{$\begin{array}{c}\text { Kompulsif Satın Alma } \\
\text { Davranışı }\end{array}$} & Gruplar Arası & 8,813 & 6 & 1,469 & \multirow{3}{*}{1,923} & \multirow{3}{*}{,075 } & \\
\hline & Gruplar İçi & 425,505 & 557 & ,764 & & & \\
\hline & Toplam & 434,319 & 563 & & & & \\
\hline
\end{tabular}

Kaynak: Yazar tarafından üretilmiştir.

Tablo 12'ye göre Etik Tüketim ve Kompulsif Satın Alma Davranışı faktörleri katılımcıların yaşadıkları bölgelere göre değişmemektedir ve H4.7 ile H6.7 reddedilmiştir ( $>>0,05)$. Ancak Hedonik tüketim faktörü ise değişmektedir ve H5.7 kabul edilmiştir $(p<0,05)$. Hedonik Tüketim faktörünün varyansı homojen olduğu için kullanılan Tukey test sonucuna göre "Karadeniz" bölgesinde yaşayanların ortalamasının "Doğu Anadolu" bölgesinde yaşayanlara göre daha yüksektir. Bu bağlamda Karadeniz bölgesinde yaşayan tüketicilerin daha fazla hedonik tüketim eğilimi gösterdiği söylenebilir.

\section{Sonuç ve öneriler}

Etik tüketim tüketicilerin çevreyi koruma, sosyal adalet ve insan hakları, bilinçli olarak satın almamak ya da boykot etmek gibi amaçlarla tüketim davranışlarına yöne veren bir anlayışı ifade etmektedir. Hedonik tüketim ise tüketicilerin ürünleri satın alırken faydacı yararlarından çok; zevk ve haza yönelik taraflarını dikkate alarak seçim karar vermesini ifade eder. Kompulsif satın alma davranışı ise tüketicinin benlik kaygıSı, imaj yaratma düşüncesi, saygınlık görme isteği, bireylerle ilişki kurma arayışı, güç ve statü talebi gibi etkenlerle satın alımlarını gerçekleştirmesini ifade etmektedir. Bu bağlamda bu çalışmada etik tüketimin hedonik tüketim ve kompulsif satın alma davranışı üzerindeki etkisi tespit edilmeye çalışılmıştır. İlk olarak verilerin basıklık ve çarpıklık değerlerinin +1 ve -1 arasında olduğu bulunmuş ve verilerin normal dağıldığı görülmüştür.

Daha sonra model PLS-SEM ile Doğrulayıcı Faktör Analizine tabi tutulmuş, araştırmada kullanılan ölçeğin geçerliliğ̣i ve güvenirliğine bakılmış ve ölçeğin yakınsak ve uyum geçerliliğini sağladığı ve ayrıca tüm faktörlerin ve ölçeğin tümünün 0,7 ve üzerinde bir katsayıya sahip olduğu yani güvenilir olduğu görülmüştür. Yine ölçeğim ayrışma geçerliliğini de sağladığı görülmüştür. Başka bir ifadeyle araştırmada kullanılan ölçeğin hem geçerli hem de güvenilir olduğu da ortaya konulmuştur. Ayrıca faktörler arasındaki korelasyon katsayılarına da bakılmış ve etik tüketim ile hedonik tüketim arasında nispeten zayıf düzeyde (\%36) ve pozitif, kompulsif satın alma davranışı ile zayıf düzeyde (\%21) ve pozitif ilişki olduğu görülmüştür. Yine hedonik tüketim ile kompulsif satın alma davranışı arasında nispeten güçlü düzeyde (\%67) ve pozitif bir ilişki olduğu da görülmüştür.

Üçüncü aşamada PLS-SEM ile araştırma modeli test edilmiştir. Modelin uyum iyiliği skorlarının kabul edilebilir aralıkta olduğu ve modelin iyi uyum gösterdiği bulunmuştur. Yine modelde faktörler arasında kurulan yol ilişkilerinden ikisinin katsayılarının da 1,96'dan büyük olduğu ancak bir tanesinin küçük olduğu ve dolayısıyla anlamlı olmadığı görülmüştür. Buna göre Etik Tüketimin Hedonik Tüketimi pozitif ve yaklaşık \%13 oranında etkilediği; Hedonik Tüketimin Kompulsif Satın Alma Davranışını pozitif ve yaklaşık \%69 oranında etkilediği ancak Etik Tüketimin Kompulsif Satın Alma Davranışı üzerinde anlamlı bir etkisinin olmadığı da görülmüştür.

Daha sonra faktörlerin katılımcıların cinsiyetine göre karşılaştırılmasında Bağımsız Örneklemler T Testi kullanılmıştır. Buna göre etik tüketimin cinsiyete göre değişmediği ancak hedonik tüketim ve kompulsif satın almanın değiştiği ve kadınların daha çok hedonik tüketim eğilimi ve kompulsif satın alma davranışı gösterdiği görülmüştür.

Faktörlerin yaş, eğitim, meslek, medeni durum, gelir ve yaşadıkları bölgeye göre karşılaştırılmasında ise Tek Yönlü F Testi kullanılmıştır. Yaş değişkenine göre yapılan karşılaştırmada faktörlerin tamamının anlamlı bir farklılık göstermediği görülmüştür. 
Eğitim durumuna göre yapılan karşılaştırmada etik tüketimin farklılık göstermediği ancak hedonik tüketim ve kompulsif satın alma davranışının farklılık gösterdiği görülmüştür. Her iki faktörde de Üniversite mezun olanların ortalamasının Lise mezunlarına göre daha yüksek olduğu görülmüştür.

Aylık ortalama gelire göre yapılan karşılaştırmada etik tüketimin farklılık göstermediği ancak hedonik tüketim ve kompulsif satın alma davranışının farklılık gösterdiği görülmüştür. Hedonik Tüketim faktöründe "4501-5500 TL" ve "5501 TL ve üstü" gruplarının ortalaması "2500 TL ve altı" olanlara göre daha yüksektir. Yine Kompulsif Satın Alma Davranışı faktöründe "4501-5500 TL" grubunun ortalaması " $2500 \mathrm{TL}$ ve altı" olanlara göre daha yüksektir. Her iki faktörde de geliri yüksek olanların daha fazla hedonik tüketim eğilimi ve kompulsif satın alma davranışı gösterdiği görülmüştür.

Medeni duruma göre yapılan karşılaştırmada etik tüketimin ve kompulsif satın alma davranışının farklılık göstermediği ancak hedonik tüketimin anlamlı bir farklılık gösterdiği görülmüştür. Hedonik Tüketim faktöründe "Bekar" olanların ortalamasının "Evli" ve "Diğer" grubundakilere göre daha yüksek olduğu görülmüştür. Buna göre bekar olanların daha fazla zevk için harcama yaptığı söylenebilir.

Meslek türüne göre yapılan karşılaştırmada etik tüketimin farklılık göstermediği ancak hedonik tüketim ve kompulsif satın alma davranışının farklılık gösterdiği görülmüştür. Hedonik tüketimde Öğrenci" olanların ortalamasının "Kamu Sektörü" çalışanlarına göre daha yüksek olduğu görülmüştür. Kompulsif Satın Alma Davranışı faktöründe ise "Özel Sektör", "Öğrenci" ve "Ev Kadını" olanların ortalamasının "Kamu Sektörü" çalışanlarına göre daha yüksek olduğu görülmüştür.

Yaşanılan coğrafi bölgeye göre yapılan karşlaştırmada etik tüketimin ve kompulsif satın alma davranışının farklılık göstermediği ancak hedonik tüketimin anlamlı bir farklılık gösterdiği görülmüştür. Hedonik tüketimde "Karadeniz" bölgesinde yaşayanların ortalamasının "Doğu Anadolu" bölgesinde yaşayanlara göre daha yüksek olduğu görülmüştür. Bu bağlamda Karadeniz bölgesinde yaşayan tüketicilerin daha fazla hedonik tüketim eğilimi gösterdiği söylenebilir.

Çalışmada ulaşılan sonuçlar daha önce yapılmış olan çalışmalardan Phau ve Woo (2008)'in sonuçlarıyla benzerlik göstermektedir. İlgili çalışmada öğrenciler aşırı harcama yapmaktadır ve bu çalışmada da öğrenciler diğer bazı mesleklere göre daha fazla kompulsif satın alma davranışı göstermektedir.

Çalışmada elde edilen sonuçlar bazı çalışmalar açısından ise farklılık arz etmektedir. Örneğin Kaderli vd. (2017)'nın çalışmasında Y kuşağından tüketiciler kompulsif satın alam davranışı gösterirken bu çalışmada ise yaş değişkenin kompulsif satın alma davranışı üzerinde bir etkisinin olmadığı ve kuşaklar açısından da farklılık göstermediği görülmüştür.

Araştırmanın en büyük kısıtlarından ilki çalışmanın nicel bir çalışma olmasıdır. İkinci en büyük kısıt çevrimiçi örnekleme yöntemiyle verilerin toplanmasıdır. Çalışmanın üçüncü en büyük kısıtı ise kullanılan istatistiksel analizler olduğu söylenebilir. Gelecek çalışmalarda nitel yöntemlerle beraber daha farklı örnekleme yöntemleri kullanılarak ve farklı analiz yöntemleriyle daha farklı sonuçlara ulaşılması mümkün olacaktır.

\section{Hakem Değerlendirmesi / Peer-review:}

Dış bağımsız

Externally peer-reviewed

\section{Çıkar Çatışması / Conflict of interests:}

Yazar(lar) çıkar çatışması bildirmemiştir.

The author(s) has (have) no conflict of interest to declare. 


\section{Finansal Destek / Grant Support:}

Yazar bu çalışma için finansal destek almadığını beyan etmiştir.

The author declared that this study has received no financial support.

\section{Etik Kurul Onayı / Ethics Committee Approval:}

$\mathrm{Bu}$ çalışma için etik kurul onayı, Sivas Cumhuriyet Üniversitesi, Sosyal Bilimler Etik Kurulu/Komitesinden 03/05/2021 tarihli E-60263016-050.06.04-45681 sayılı karar ile alınmıştır.

Ethics committee approval was received for this study from Sivas Cumhuriyet University, Social Sciences Ethics Committee on 03/05/2021 and E-60263016-050.06.04-45681 document number.

\section{Kaynakça / References}

Alba, J. W. \& Williams, F. E. (2013). Pleasure principles: A review of research on hedonic consumption. Journal of Consumer Psychology 23(1); 2-18. http://dx.doi.org/10.1016/j.jcps. 2012.07.003

Alsaad, K. A. (2021). Ethical judgment, subjective norms, and ethical consumption: The moderating role of moral certainty. Journal of Retailing and Consumer Services 59;1-8. https://doi.org/10.1016/j.jretconser.2020.102380

Antonetti, P., Maklan, S., (2014). Feelings that make a difference: how guilt and pride convince consumers of the effectiveness of sustainable consumption choices. J. Bus. Ethics 124, 117-134. https://doi.org/10.1007/s10551-013-1841-9.

Aygün, H. (2018). Tüketici davranışlarının satın alma niyeti üzerindeki etkisinde etiğin aracı rolü. International Social Sciences Studies Journal, 4(23): 4666-4684

Babin, B.J., Darden, W.R., Griffin, M., 1994. Work and/or fun: measuring hedonic and utilitarian shopping value. Journal Consumer Research. 20 (4), 644-656.

Başaran, Ü., \& Büyükyılmaz, O., (2015). The effects of utilitarian and hedonic values on young consumers satisfaction and behavioral intentions. Eurasian Journal of Business and Economics, $8(16), 1-18$.

Bettman, J.R., Luce, M.F., Payne, J.W., (1998). Constructive consumer choice processes. J. Consum. Res. 25 (3), 187-217.

Black, D. W. (2007). “Compulsive Buying Disorder: A Review Of The Evidence”, CNS Spectrums, 12, 124-132.

Carrigan, M., Szmigin, I., Wright, J., (2004). Shopping for a better world? An anterpretive study of the potential for ethical consumption within the older market Journal Consumer Marketing. 21 (6), 401e417. https://doi.org/10.1108/07363760410558672.

Carrington, M.J., Neville, B., (2016). The ideology of the ethical consumption gap. Market. Theor. 16 (1), 21-38. https://doi.org/10.1177/1470593115595674

Carrington, M.J., Neville, B.A., Whitwell, G.J., (2010). Why ethical consumers don't walk their Talk : towards a framework for understanding the gap between the ethical purchase intentions and actual buying behaviour of ethically minded. J. Bus. Ethics 97, 139-158. https://doi.org/10.1007/s10551-010-0501-6.

Chin, W. W., \& Newsted, P. R. (1999). Structural Equation modeling analysis with small samples using partial least squares. In: Hoyle R (Ed.), Dtatistical strategies for small sample research (pp.307-341). Thousand Oaks, CA: Sage Publications.

Chow, W. S., \& Chen, Y. (2012). Corporate sustainable development: Testing a new scale based on the mainland Chinese context. Journal of Business Ethics, 105(4), 51-533. 
Dedeoglu, B.B., Bilgihan, A., Ye, B.H., Buonincontri, P., Okumus, F., (2018). The impact of servicescape on hedonic value and behavioral intentions: the importance of previous experience. Int. J. Hosp. Manag. 72, 10-20.

Dittmar, H. (2005). Compulsive buying-a growing concern? an examination of gender, age, and endorsement of materialistic values as predictors, British Journal of Psychology, 96(4), 467-491.

El-Adly, M. and Eid, R.(2015). Measuring the perceived value of malls in a non-western context: the case of the UAE. Int. J. Retail Distrib. Manag. 43(9), 849-869.

El-Adly, M.I., Eid, R., (2016). An empirical study of the relationship between shopping environment, customer perceived value, satisfaction, and loyalty in the UAE malls context. J. Retail. Consum. Serv. 31, 217-227.

Eroğlu, F. (2015). Kompulsif satın alma eğiliminde kişisel faktörlerin, postmodern tüketim şekillerinin ve bir pazarlama çabası olarak reklamın rolü. (Doktora Tezi), İstanbul: İstanbul Üniversitesi.

Faber, R.J. and O'Guinn, T.C. (1992). A clinical screener for compulsive buying, Journal of Consumer Research. 19, 459-469.

Fornell, C. ve Larcker, D.F. (1981). Evaluating structural equation models with unobservable variables and measurement error. Journal of Marketing Research, 18, 39-50.

Hair, J. F., Black, W. C., Babin, B. J., Anderson, R. E., \& Tatham, R. L. (2013). Multivariate Data Analysis. Pearson Education Limited.

Hanzaee, K. H., \& Khonsari, Y. (2011). A review of the role of hedonic and utilitarian values on customer's satisfaction and behavioral intentions. Interdisciplinary Journal of Research in Business, $1(5), 34-45$

Henseler, J., Christian M.R. ve Sarstedt, M. (2015). A new criterion for assessing disci-rimant validity in variance-based structural equation modeling. Journal of the Academy of Marketing Science, 43, 115-135.

Hepola, J., Leppäniemi, M. \& Karjaluoto, H. (2020). Is it all about consumer engagement? Explaining continuance intention for utilitarian and hedonic service consumption. Journal of Retailing and Consumer Services 57; 1-9. https://doi.org/10.1016/j.jretconser.2020.102232

Hirschman, E. C., \& Holbrook, M. B. (1982). Hedonic consumption: Emerging concepts, methods and propositions. Journal of Marketing, 46(3), 92-101. http://dx.doi.org/10.2307/1251707

Joseph F. Hair, Jr., G. Tomas M. Hult, Christian Ringle, Marko Sarstedt (2016). A Primer on Partial Least Squares Structural Equation Modeling (PLS-SEM). Edition 2.

Kaderli, Y., Aksu Armağan, E, Küçükkambak, S. (2017). Y kuşağının kompulsif satın alma davranışına etki eden faktörler üzerine bir araştırma. İstanbul Üniversitesi İşletme Fakültesi Dergisi, 46(2) , 188210 . Retrieved from https://dergipark.org.tr/tr/pub/iuisletme/iss ue/36314/410283

Karaboğa, K., Eroğlu Pektaş, G.Ö. (2020). Kompülsif satın alma davranış düzey ve biçimlerinin belirlenmesi üzerine kuşaklar arası deneyimsel bir araştırma. Üçüncü Sektör Sosyal Ekonomi Dergisi, 55(1), 155-172

Karahan, M.O., Söylemez, C. (2019). Tüketicilerin kompulsif satın alma davranışını etkileyen faktörler: bir uygulama, İşletme Araştırmaları Dergisi, 11 (3), 1961-1975.

Korur M. G, Kimzan H. S (2016). Kompulsif satın alma eğilimi ve alışveriş sonrası pişmanlık ilişkisinde kontrolsüz kredi kartı kullanımının rolü: avm müşterileri üzerine bir araştırma. Tüketici ve Tüketim Araştırmaları Dergisi, 8(1), 43 - 71.

Kushwah, S., Dhir, A., Sagar, M., 2019. Ethical consumption intentions and choice behavior towards organic food. Moderation role of buying and environmental concerns. J. Clean. Prod. 236 https://doi.org/10.1016/j.jclepro.2019.06.350, 117519.

Maccarrone-Eaglen A. and Schofield, P. (2017). Compulsive buying behavior: Re-evaluating its dimensions and screening. J Consumer Behav.16 :463-473. https://doi.org/10.1002/ cb.1652 
McElroy, S, Phillips, K, Keck, P., (1994). Obsessive compulsive spectrum disorder. Journal of Clinical Psychiatry, 55, 33-53.

Nakip, M. (2013). Pazarlama Araştırma Teknikleri: SPSS Uygulamalı. Seçkin Yayıncılık.

Phau, I. ve Woo, C. (2008). Understanding compulsive buying tendencies among young australians, Marketing Intelligence and Planning, 26, 441-458.

Shaw, D.S., Clarke, I., (1998). Culture, consumption and choice: towards a conceptual relationship. J. Consum. Stud. Home Econ. 22 (3), 163-168. https://doi.org/10.1111/j.1470-6431.1998.tb00727.x.

Sudbury, R. L., \& Kohlbacher, F. (2015). Ethically minded consumer behaviour: scale review, development and validation. Journal of Business Research, 69, 2697-2710.

Sudbury, R. L., \& Kohlbacher, F. (2015). Ethically minded consumer behaviour: scale review, development and validation. Journal of Business Research, 69, 2697-2710.

Szmigin, I., Maddock, S., Carrigan, M., (2006). Conceptualising community consumption. Br. Food J. 105 (8), 542e550. https://doi.org/10.1108/00070700310497291.

Tavşancıl, E. (2002). Tutumların ölçülmesi ve spss ile veri analizi. Nobel Yayıncılık.

Valence, G., D'Astous, A. \& Fortier, L. (1988). Compulsive Buying: Concept and Measurement, Journal Of Consumer Policy, 11, 419-433.

Voss, K.E., Spangenberg, E.R., Grohmann, B., (2003). Measuring the hedonic and utilitarian dimensions of consumer attitude. Journal Marketing Research. 40 (3), 310-320.

Yaşar, M. (2017). Hedonik ve faydacı tüketim bağlamında tüketici davranışlarının incelenmesi: Gençlerin hedonik tüketim eğilimlerini belirlemeye yönelik bir araştırma (Yayınlanmamış doktora tezi). Dumlupınar Üniversitesi, Kütahya.

Yaşlığlu, M. (2017). Sosyal bilimlerde faktör analizi ve geçerlilik: keşfedici ve doğrulayıcı faktör analizlerinin kullanılması. İstanbul Üniversitesi İşletme Fakültesi Dergisi,ss.74-85. Retrieved from https://dergipark.org.tr/tr/pub/iuisletme/issue/32177/357061 